\title{
The lugworm Arenicola marina: a model of physiological adaptation to life in intertidal sediments
}

\author{
E. Zebe $^{1} \&$ D. Schiedek ${ }^{2}$ \\ ${ }^{1}$ Institut für Zoophysiologie, Westf. Wilhelms-Universität; Hindenburgplatz 55, \\ D-48143 Münster, Germany \\ ${ }^{2}$ Institut für Ostseeforschung Warnemünde an der Universität Rostock; Seestr. 15, \\ D-18119 Rostock, Germany
}

Manuscript received on 30th January 1994; accepted for publication on 1st August 1994

ABSTRACT: The results of more than two decades of intensive research on the physiological and biochemical features of the lugworm are reviewed with the aim of drawing a general and comprehensive picture of the adaptation of this species to the special conditions of living in the tidal zone, which may also hold true for the majority of invertebrates found in this habitat.

\section{INTRODUCTION}

In his monograph on the lugworm Arenicola marina, F. Krüger (1971) outlined the current state of knowledge concerning morphological organization and physiology of this polychaete. Since then the lugworm has, for several reasons, become a popular object of physiological and biochemical studies:

(1) It is one of the largest annelids and has a rather simple anatomical organization with a large coelomic cavity extending through most of the body without segmental subdivisions. This makes experimental manipulations, such as injections, particularly easy.

(2) It is found in dense populations in the tidal zone throughout the North Sea coast. Hence the supply, even of large numbers of specimens, is easy. Moreover, lugworms can be maintained in ciruculating sea water for several weeks, which renders it feasable to use them in places distant from the coast.

(3) A. marina is well adapted to the special conditions of the tidal zone and, therefore, exhibits particular physiological properties which have attracted the interest of a growing number of scientists.

During the last two decades, many experimental investigations have been conducted which have yielded a wealth of new results. As a consequence, Arenicola has become one of the most extensively studied members of the littoral fauna and, therefore, may be considered a model which shows particularly clearly the special physiological properties necessary for living in extreme habitats such as the tidal zone.

Many of the new findings have already been treated in reviews stressing special points of view (Schöttler, 1980, 1986; Schöttler \& Bennett, 1991; Kamp, 1992). After two 
decades of active research it now seems appropriate to give a more general survey on the physiology of Arenicola based on the many and diverse data gained since Krüger's report.

\section{NUTRITION AND DIGESTION}

The lugworm is a well-known example of a direct deposit feeder. It ingests material from the base of a column which extends vertically from the horizontal part of its burrow to a funnel-like cavity at the sediment surface. This "feeding column" (measuring $5 \mathrm{~mm}$ in diameter and about $20 \mathrm{~cm}$ in length) is particulary rich in organic material (Rijken, 1979), probably because the funnel functions as a trap collecting detritus as this settles on the surface of the sediment. The feeding activity of the lugworm causes the material to move from the funnel through the whole length of the column in a few hours. At the base, the worm preferentially takes up small particles which easily stick to the mucus lining the papillae of its proboscis, whereas larger particles are rejected and, as a consequence, accumulate in the vicinity of the burrow (Baumfalk, 1979b). Such selective removal of certain components from the column may result in a heterogenous distribution of particles of different size in the sediment.

In the past, the question as to what actually is the food of the lugworm has been extensively and controversely discussed (Rijken, 1979). Direct utilization of detritus, in particular that of plant origin, appears unlikely, because its components are highly resistant to degradation. However, breakdown of detritus is accomplished by bacteria which thrive on the rich deposits present in the sediment. Therefore, Arenicola probably uses microorganisms as the most important source of food. Benthic diatoms and meiofauna found in the feeding column probably are an additional food component, although their quantitative significance in this respect is difficult to evaluate.

The lugworm may also filtrate the respiratory water to obtain plankton and suspended particles (Krüger, 1958b; Hobson, 1967). It seems doubtful, however, that this can significantly contribute to the food balance, because the volume of respiratory water is small in absolute terms: $10-20 \mathrm{ml} \cdot \mathrm{g}^{-1} \cdot \mathrm{h}^{-1}$. According to Hylleberg-Kristensen (1975), microorganisms should particularly thrive in the "feeding column" and hence rapidly increase in their mass due to the favourable conditions for growth and reproduction. However, considering the comparatively fast turnover of material composing the column, it seems difficult to imagine that this "gardening" could supply significant quantities of additional food.

Feeding experiments in the laboratory were especially important to determine what kind of material Arenicola actually utilizes as food (Rijken, 1979). They revealed that specimens, which, during a period of several weeks, were fed only bacteria, gained substantially in weight indicating an effective digestion. A parallel group fed diatoms as sole food also increased its weight, although clearly less than the former. Fairly negative effects were observed in a third group fed pulverized algal material. These specimens exhibited only minimal growth and some even died. On the other hand, feeding stuff that had been scraped off the sediment surface resulted in maximal growth of the respective experimental animals. Summarizing these results, it is evident that the lugworm can effectively utilize detritus, although only in an indirect manner, i.e. via microorganisms and meiofauna, while microphytobenthos may represent an additional minor food source.

Early studies on the digestive physiology of Arenicola were mainly concerned with 
the functional differentiation of the gut and, in addition, have qualitatively analysed the hydrolysis of various compounds assumed to be components of the natural food (Kermack, 1955; Longbottom, 1970; Hylleberg-Kristensen, 1972). They have demonstrated that carbohydrate and protein degradation are accomplished solely by preparations of the oesophagus diverticula and the so-called stomach. Obviously, these sections of the gut must be the centres of digestion.

Analysing the digestive processes quantitatively, Eberhardt (1988) observed that glycogen, starch and maltose were very rapidly hydrolysed, whereas degradation of lipids was slow. Furthermore, he demonstrated an extremely high proteolytic capacity and a very rapid splitting of $\beta$-glucosidic and $\beta$-glucosaminic bonds as well as of phosphate bonds which seem typical features of the alimentary system of Arenicola. Eberhardt (1988) also confirmed that the digestive enzymes responsible for the breakdown of the compounds mentioned above mainly occur in the diverticula of the oesophagus and in the anterior part of the "stomach". The enzymatic pattern was constant and did not change significantly even during extended starvation periods. This indicates that digestive enzymes are virtually continuously synthesized and secreted which coincides with the sustained digestion typical of the natural habitat. The strikingly high activities of the digestive enzymes are probably necessary regarding the fast passage of the food through the gut, i.e. the short period of digestion. The time measured between the ingestion of labelled material and its appearance in the faeces was 30 to 60 minutes (Jacobsen, 1967; Rijken, 1979). According to Eberhardt (1988), the extremely high proteolytic activity may be seen in relation to the indirect utilization of detritus by Arenicola. Utilizing bacteria (which are the most important component of food) will depend on rapid permeation of the proteinases through the cell wall and, subsequently, on effective degradation of cell membrane proteins. Although there is no direct evidence supporting this assumption, it seems most likely that the proteinases of the stomach are highly effective in this respect.

Thus far, no lysozyme activity has been detected in the lugworm (Eberhardt, 1988). This could be due to technical difficulties resulting from tests developed for the special conditions of vertebrates which are ineffective at a salinity three times higher than that in mammalian systems. Furthermore, marine bacteria may have properties which substantially differ from those of the bacteria specialized in living as mammalian parasites.

In any case, an effective digestion of masses of bacteria in the gut of Arenicola has been convincingly demonstrated by the feeding experiments described above (Rijken 1979; Liefken at al., 1979).

Five individual proteolytic enzymes have been isolated, purified and characterized (Eberhardt, 1992). As indicated by the effect of specific inhibitors, all turned out to be serine proteases with nearly identical molecular masses (appr. $24 \mathrm{kDa}$ ), isoelectric points between $\mathrm{pH} 3.5$ and 5.7 and $\mathrm{pH}$-optima ranging from 8.0 to 8.5. Unlike vertebrate digestive proteases, the lugworm enzymes were stable in solution, i.e. there was no loss of activity by "autodigestion" even during several days at room temperature. No inactive proenzymes were detected. Analysing the specifity of catalytic action with the B-chain of insulin as substrate, Eberhardt found three distinct trypsin-like enzymes, whereas the two others were similar to vertebrate chymotrypsin and elastase, respectively. Additional endopeptidases and the exopeptidases present in the digestive system of Arenicola have not yet been purified and characterized. 
The lugworm (like several other marine invertebrates) is capable of absorbing "dissolved organic matter" (DOM) from the ambient water. Thus, it may employ a second mode of nutrition in addition to ingesting food. Experimental evidence shows the uptake of short-chain fatty acids through the body-wall (Holst \& Zebe, 1984). Obviously, this absorption requires a sufficient supply of oxygen, for it was found to cease under hypoxic conditions.

The rate of propionate absorption was higher than that of butyrate and acetate. Uptake of all these fatty acids exhibited saturation kinetics. Absorption of propionate was inhibited by the presence of butyrate and acetate (maximal inhibition $78 \%$ ). This result suggests that a carrier is involved. After their uptake the fatty acids were rapidly converted, mainly to aspartate, glutamate and alanine.

The ability of the lugworm to absorb fatty acids from the ambient water may be related to the occurrence of propionate and acetate in its habitat. These fatty acids originate from the anaerobic metabolism of microorganisms present in the sediment. Their concentration in interstitial water sometimes exceeds $10 \mu \mathrm{mol} \cdot \mathrm{l}^{-1}$ (Zebe, unpublished results). At the present, it is not known whether Arenicola actually makes use of its particular ability; therefore, its significance with respect to nutrition cannot be appraised.

\section{RESPIRATION}

The lugworm lives in a virtually anoxic environment and must obtain its oxygen from the overlying water. This requires continuous pumping to irrigate the burrow and to maintain the respiratory gas exchange. The mechanism of pumping and the behaviour involved in irrigation has been extensively studied by Wells (1949) and Krüger (1958b, 1964). Pumping activity proceeds in cycles which last approximately 40 minutes in large specimens, while they are considerably shorter in smaller ones. The cycles are probably under the control of a pace-maker situated in the nervous system. They can be observed even in individuals taken out of their burrows and placed in free water.

The pumping effect results from contractions of the longitudinal muscles which cause the diameter of the body to increase, until the lumen of the burrow is completely closed. The contractions start at the posterior end of the main body (i.e. at the base of the "tail") and are slowly propagated towards the "head". The contracted section acts like a piston in a cylinder pushing the water in front of it ahead and sucking in oxygen-rich water from behind, i.e. from above the sediment surface.

The pumping rate ranges between 8 and $26 \mathrm{ml} \cdot \mathrm{g}^{-1} \cdot \mathrm{h}^{-1}$ (Krüger, 1964; Mangum, 1976; Baumfalk, 1979a). In Arenicola cristata (100 g weight as compared to 5-10 $\mathrm{g}$ in $A$. marina), the rate is about a fourth of that measured in the latter species. On the other hand, considerably higher rates have been measured in Abarenicola affinis under laboratory conditions (Barrow \& Wells, 1982). Although the usual irrigation rate seems low, it is sufficient to maintain a mean $\mathrm{pO}_{2}$ of at least 70 Torr in the burrow water (Mangum, 1973). As soon as the pumping stops, the oxygen level declines rapidly.

Wells (1949) has proposed that Arenicola might be able to take up oxygen from the air. While studying the irrigation behaviour of specimens in artificial burrows made of glass, he had observed that, at low water levels, air bubbles were sometimes moving with the contraction waves along the body of the worm. Although this would be indeed an efficient mode of obtaining oxygen, no experimental evidence exists at present which 
supports this hypothesis. Moreover, it is not known whether lugworms irrigating the burrows in their natural habitat actually pump air bubbles together with water. (Aerial respiration has also been reported in Abarenicola pacifica without mentioning concrete experimental results: Hobson as cited by May, 1972). More recent studies have shown that in the natural habitat Arenicola accumulates anaerobic endproducts during low tide (Toulmond, 1973; Pionetti \& Toulmond, 1980; Schöttler et al., 1983). This seems to preclude a significant role of aerial respiration.

Arenicola has 13 pairs of highly branched gills which, in certain phases of the pumping cycle, are completely retracted into the coelomic cavity. The respiratory gas exchange, however, is not limited to the gill epithelium, but takes place also at the undifferentiated body surface. This has been demonstrated by Mangum (1976) who analysed the oxygen content of the water in different sections of the burrow (Fig. 1). According to her data, more than $75 \%$ of the oxygen is indeed taken up via the gillbearing segments (although some of that probably enters the body through the epidermis instead of the gill epithelium). Mangum estimates that almost equal amounts of oxygen are taken up by the gills and by the undifferentiated surface. This would mean that at least half of the oxygen is supplied directly to the cells (mainly of the body-wall), whereas $50 \%$ or less are carried by the blood to supply the internal organs such as nervous system, gut epithelium and chloragogen tissue.

By its respiration the lugworm extracts between 32 and $40 \%$ (58\% in A. cristata) of the oxygen present in the burrow water (Mangum, 1976). This seems to be low in comparison with some fish species that can extract more than $90 \%$. As Mangum (1976) emphasizes, the organisation of the gills and the circulatory system of Arenicola is rather primitive and hence cannot be expected to function as efficiently as in the more advanced

62

146

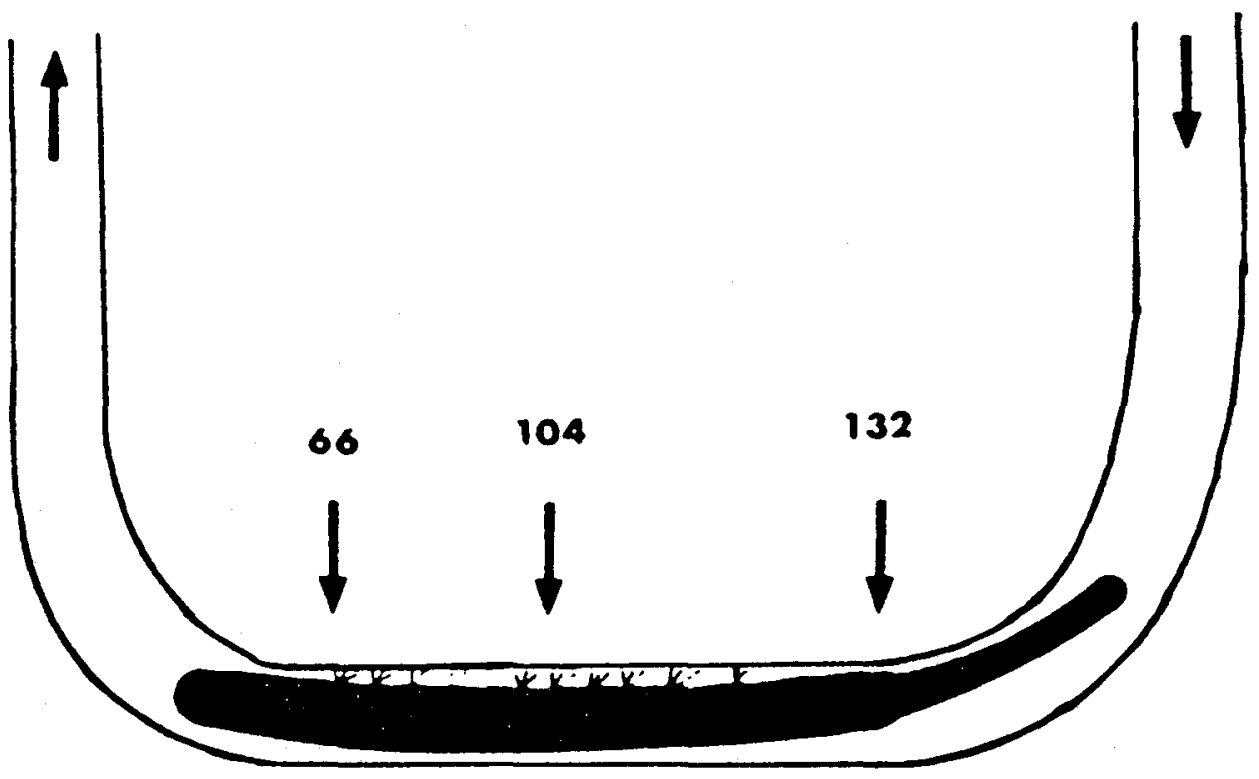

Fig. 1. $\mathrm{pO}_{2}$ measured in different parts of the burrow of Arenicola cristata (from Mangum, 1976) 
systems of higher animals such as fish. The gills consist of bundles of ramifying and highly contractile tubes filled with blood. They are emptied, when they are withdrawn into the coelomic cavity as the respective segments increase in diameter during pumping or locomotory activity. It seems doubtful whether in the expanded state there is an efficient and continuous blood transport. In any case, a counter-current exchange between water and blood like that in the fish gill seems impossible in Arenicola (Mangum, 1976).

Under normoxic conditions (i.e. during high tide), the rate of oxygen uptake by the lugworm amounts to $5-14 \mu \mathrm{l} \cdot \mathrm{g}^{-1} \cdot \mathrm{h}^{-1}$ at $6^{\circ} \mathrm{C}, 22 \mu \mathrm{l}$ at $14^{\circ} \mathrm{C}$, and $11-27 \mu \mathrm{l}$ at $23^{\circ} \mathrm{C}$ (Mangum, 1976; Schöttler, 1989). When the habitat emerges at low tide and the supply of oxygen-rich water is interrupted, the lugworm reduces its movements to a minimum. Also, perfusion of the gills virtually ceases and the whole circulation declines. As a consequence, gas exchange stops and the $\mathrm{pO}_{2}$ in the blood drops from 6 to 1 Torr, whereas the $\mathrm{pCO}_{2}$ rises from 0.4 to 2.0 Torr and higher and the $\mathrm{pH}$ declines from 7.48 to 7.35 (Toulmond, 1973: Wells, 1974).

From studies of Abarenicola pacifica, it appears that this species is able to maintain a mean oxygen content of about $1 \mathrm{ml} \cdot \mathrm{l}^{-1}$ in the burrow water even at low tide, which results in a low respiratory rate $\left(2 \mu \mathrm{l} \cdot \mathrm{g}^{-1} \cdot \mathrm{h}^{-1}\right.$, temperature ?; May, 1972).

Respiratory measurements in the laboratory revealed constant rates of oxygen consumption at $\mathrm{pO}_{2}$ ranging from 120 to 500 Torr (Toulmond \& Tschernigovtzeff, 1984; Conti \& Toulmond, 1986; Dejours \& Toulmond, 1988). This is accomplished by variation of the pumping activity. At $\mathrm{pO}_{2}$ higher than 160 Torr the irrigation rate is reduced, whereas it is increased when the $\mathrm{pO}_{2}$ declines below 160 Torr. At $\mathrm{pO}_{2}$ below 120 Torr, pumping activity decreases rapidly, until, at about 50 Torr, it stops completely. The course of oxygen consumption is similar, being constant at high oxygen levels and decreasing parallel to the $\mathrm{pO}_{2}$ (Shumway, 1979).

Other parameters such as temperature, body mass, season and reproductive state may also influence the lugworm's rate of oxygen consumption.

In the uptake of oxygen via the gills, the hemoglobin present in the blood plays a key role. This has been demonstrated by applying carbon monoxide which inhibits the binding of oxygen by hemoglobin. The respiratory rate was then markedly reduced (maximal inhibition: $40 \%$; Krüger, 1959; Mangum 1976). At $6^{\circ} \mathrm{C}$ the inhibitory effect was much smaller than at $20^{\circ} \mathrm{C}$. Maximal inhibition occurred at $\mathrm{pO}_{2}$ between 120 and 30 Torr (150 and 40 Torr in $A$. cristata), whereas it was comparatively low at high $\mathrm{pO}_{2}$. These results indicate a function of hemoglobin in oxygen uptake especially at intermediate $\mathrm{pO}_{2}$ (as it presumably prevails in the burrow under normal conditions), whereas the significance of the pigment declines at higher as well as at very low oxygen levels and, in addition, at low temperatures. With respect to the role of hemoglobin, another result is especially interesting; when gill function was prevented by ligations, this not only resulted in a decrease of the respiratory rate, but it was virtually identical in extent with the inhibitory effect of CO on hemoglobin (Mangum, 1976).

\section{CIRCULATION AND BODY FLUIDS}

Arenicola has a closed system in which the blood is circulated through the whole body in a matter of a few minutes. On the other hand, the coelomic fluid, whose volume is 
6 to 10 times larger than that of blood (Toulmond, 1971a), has a static function. In addition, in pumping and locomotory activities, it functions as a component of a hydraulic system, being shifted from one part of the body to another. This is possible because in the lugworm the coelomic cavity is not subdivided by dissepiments, as in many polychaete species, except in the "tail".

Due to high concentrations of extracellular hemoglobin in the blood $10-14 \mathrm{~g}$ $\left.100 \mathrm{ml}^{-1}\right)$ its oxygen capacity is high $\left(7 \mathrm{ml} \cdot 100 \mathrm{ml}^{-1}\right.$ in $A$. marina and $13 \mathrm{ml} \cdot 100 \mathrm{ml}^{-1}$ in A. cristata: Toulmond, 1973; Mangum, 1976). On the other hand, no hemoglobin and very little protein are present in the coelomic fluid; the oxygen capacity is accordingly low.

The molecular organization of hemoglobin has been extensively analysed in the American species A. cristata (Waxman, 1971). It is an extremly large molecule (2850 kDa) containing 96 heme groups which is made up of two identical disc-shaped halves, each of these composed of six subunits of $230 \mathrm{kDa}$. The subunits consist of four polypeptide chains ( 2 of $13 \mathrm{kDa}$ and 2 of $14 \mathrm{kDa}$ ) and two heme groups. In Abarenicola pacifica, the hemoglobin molecule is slightly smaller than in A. cristata: $2600 \mathrm{kDa}$ (Garlick \& Terwilliger, 1977).

Characteristic properties of lugworm hemoglobin are a high oxygen affinity $(\mathrm{p} 50=$ $2.0-2.5$ ) and a pronounced cooperativity. The cooperativity is heterogenous; it increases with rising oxygenation and, in addition, with rising $\mathrm{pH}$ in the physiological range between 7.1 and 7.4 (Weber, 1978). Furthermore, anorganic anions can influence oxygen affinity as well as cooperativity of Arenicola hemoglobin, but the significance of this effect with regard to its role under the conditions of the natural habitat appears doubtful (Everaarts \& Weber, 1974; Krogh-Rasmussen \& Weber, 1979). It seems noteworthy that the analytical data of hemoglobins obtained from various lugworm species differ somewhat (Garlick \& Terwilliger, 1977).

Because of the strongly sigmoid dissociation curve, comparatively large quantities of oxygen can be bound or released in response to small changes of $\mathrm{pO}_{2}$.

The hemoglobins of some species of Arenicola differ markedly with respect to the Bohr effect. It is particulary large in A. marina, but rather small in A. cristata, whereas the values measured in Abarenicola claparedi and Arenicoloides branchialis are intermediate. Weber (1972) presumes that these differences are due to the adaptation of each species to the particular conditions of its habitat. On the other hand, Mangum (1976) concludes from her results that in Arenicola the functional significance of the Bohr effect with regard to oxygen transport is probably low.

The $\mathrm{pO}_{2}$ in the blood of the lugworm is low: in post-branchial blood, values ranging between 3 and 6 Torr have been measured at high tide and 1 Torr at low tide (Toulmond, $1973,1975)$. These low oxygen levels result from the high oxygen affinity of hemoglobin and, in addition, especially from the mixing of oxygenated and non-oxygenated blood in the primitive circulatory system, as has been emphasized by Mangum (1976).

In the coelomic fluid of normally respiring lugworms, the $\mathrm{pO}_{2}$ is so high that a supply of oxygen from the blood will hardly occur. However, in summer, conditions are different: large masses of gametes develop in the coelomic cavity, while the environmental temperature rises. The growing demand for oxygen by the developing cells then results in a drastic reduction of the $\mathrm{pO}_{2}$ in the coelomic fluid (Mangum, 1976; Schöttler, 1989).

The body-wall tissue contains myoglobin, which seems to be a mixture of two distinct varieties that differ with respect to oxygen affinity ( $\mathrm{p} 50=0.8$ and 1.5 Torr) and isoelectric 
point (6.3 and 8.0; Weber \& Pauptit, 1972). SDS-electrophoresis of A. pacifica myoglobin, however, revealed a single band indicating an apparent molecular mass of $15.3 \mathrm{kDa}$ (Garlick \& Terwilliger, 1977). Since the oxygen affinity of the myoglobins is clearly higher than that of hemoglobin, they could enhance the transfer of oxygen from the blood to the muscles. Very likely, these pigments are involved in the intracellular distribution of oxygen by means of facilitated diffusion. Moreover, an equally important function of lugworm myoglobin probably consists in taking up oxygen directly from the ambient water, and this obviously proceeds at a high rate.

Only few data are available on the transport of $\mathrm{CO}_{2}$ in the lugworm. It appears that it occurs mainly as hydrogen carbonate, whereas a few percent of the total are transported in physical solution and bound to hemoglobin by carbamino formation. At a $\mathrm{pCO}_{2}$ of 3 Torr (the maximum value measured in prebrachial blood; Toulmond, 1973), the $\mathrm{CO}_{2}$ capacity of Arenicola blood amounts to 7 vol\% (Weber, 1978).

According to Toulmond (1971b), there is a pronounced Haldane effect, i.e. oxygenation of hemoglobin results in a decrease of $\mathrm{CO}_{2}$-binding capacity, which favours its release in the gills. Rapid hydration of $\mathrm{CO}_{2}$ is accomplished by a specific carboanhydrase in lugworm blood (Wells, 1973). Unlike that of vertebrate blood, it is not bound to cells or other structural elements, but occurs in solution in the "plasma". On the other hand, no carboanhydrase activity has been detected in gill tissue and coelomic fluid.

Arenicola carboanhydrase (like that in vertebrate blood) is inhibited by acetazolamide (Wells, 1973). When the inhibitor was applied to aerobic lugworms, the $\mathrm{pH}$ of blood and coelomic fluid decreased markedly within one hour, whereas no effect was observed in anaerobic specimens. This illustrates the role of carboanhydrase in the elimination of $\mathrm{CO}_{2}$.

\section{ANAEROBIC METABOLISM}

In the natural habitat, the oxygen supply of the lugworm is cut off twice daily when, at low tide, the water recedes for several hours. (Some places may even occasionally emerge for several tidal cycles.) This means that the animal must regularly switch from the normal aerobic metabolism to anaerobiosis which is characterized by a very low yield of ATP. The transition requires a period of several hours and proceeds in a sequence of phases with typical metabolic changes. This has been analysed in detail by Schöttler et al. (1984b).

At the onset of hypoxia (in the so-called transition phase which lasts about three hours), ATP is resynthesized mainly by transphosphorylation from phosphotaurocyamine, the special phosphagen of the lugworm which is present in the body-wall musculature in comparatively high concentration (Surholt, 1977b, 1979). Its breakdown results in an increase of inorganic phosphate which can be observed in intact animals by means of ${ }^{13} \mathrm{P}-\mathrm{NMR}$ spectroscopy (Kamp \& Juretschke, 1989a). Concomitantly, degradation of glycogen is activated as shown by ${ }^{13} \mathrm{C}-\mathrm{NMR}$ technique (Juretschke \& Kamp, 1990a). As a consequence, the rate of pyruvate formation increases, but there is no accumulation of lactate, because the activity of $\mathrm{LDH}$ is very low in Arenicola. Instead, pyruvate serves as a substrate in two other reactions (Fig. 2).

A minor portion is condensed with glycine to strombine. This reaction is catalyzed by a very active strombine dehydrogenase and reoxidizes $\mathrm{NADH}$, i.e. it is analogous to the formation of lactate in normal glycolysis (Siegmund et al., 1985). 


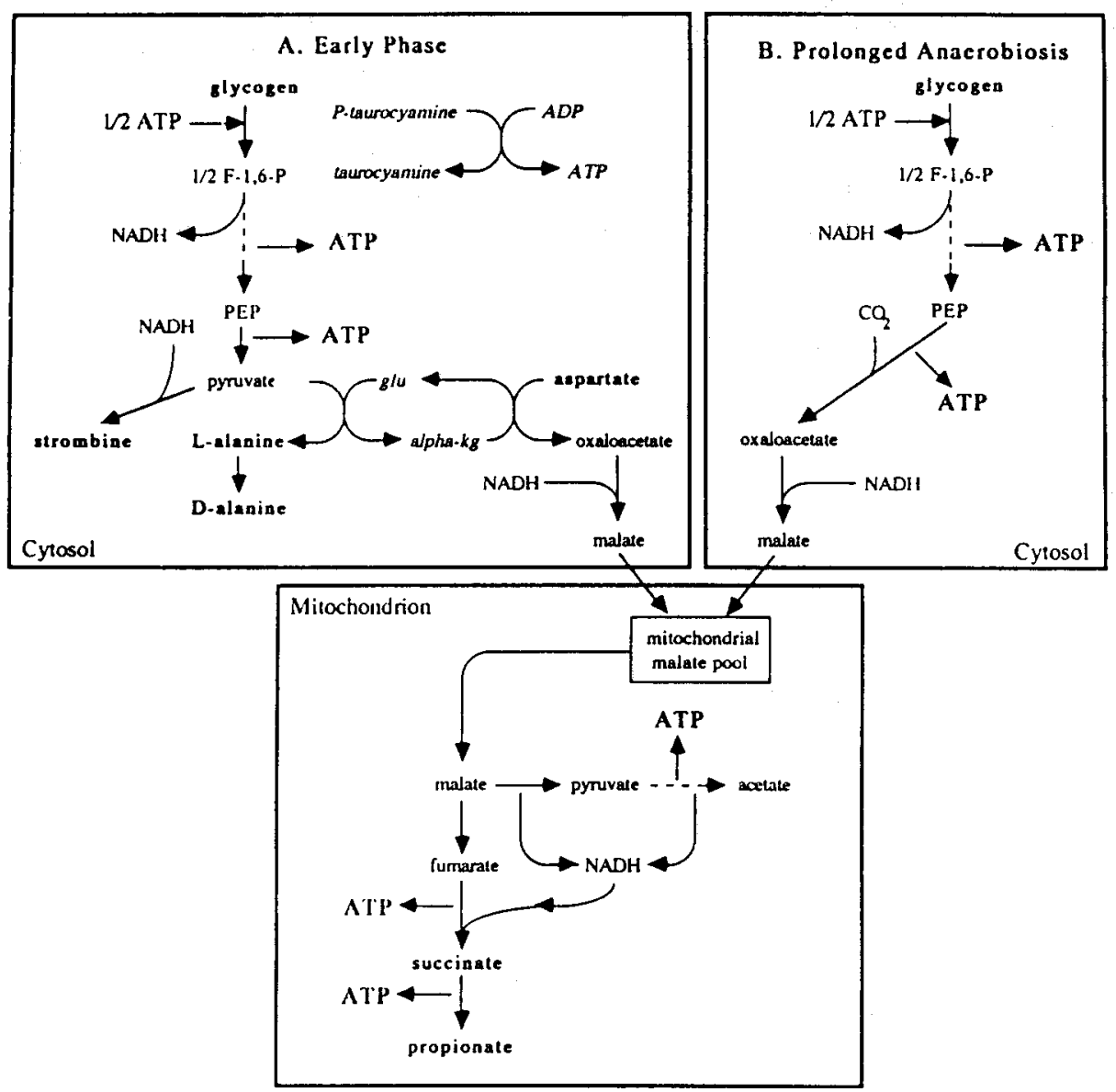

Fig. 2. Pathways of metabolism in Arenicola marina in different phases of anaerobiosis (from Schöttler \& Bennett, 1991). A: transition phase, B: prolonged anaerobiosis

A major quantity of pyruvate functions as an acceptor of the amino group in the reductive transamination of aspartate whose utilization is also induced by hypoxia. In this process, three different enzymes cooperate: aspartate aminotransferase, alanine aminotransferase and malate dehydrogenase (Felbeck, 1980; Felbeck \& Grieshaber, 1980). Since NADH is reoxidized, the redox balance is maintained:

\begin{tabular}{lll}
$(1)$ aspartate + oxoglutarate & $\longrightarrow$ & glutamate + oxaloacetate \\
(2) glutamate + pyruvate & $\longrightarrow$ & alanine + oxoglutarate \\
(3) oxaloacetate $+\mathrm{NADH}$ & $\longrightarrow$ & malate $+\mathrm{NAD}^{+}$ \\
\hline aspartate + pyruvate $+\mathrm{NADH}$ & $\longrightarrow$ & alanine + malate $+\mathrm{NAD}^{+}$
\end{tabular}

At this point it has to be mentioned that the quantity of accumulated alanine not only exceeds that of strombine by a factor of 10 , but is regularly substantially higher than that of the aspartate utilized. This suggests that additional compounds, still unknown, do 
participate in the transamination reactions. It is noteworthy that, in addition to L-alanine, also D-alanine is accumulated in approximately equimolar amounts (Felbeck, 1980), which is due to the presence of a racemase (Sticher, 1985).

Unlike alanine, which accumulates in the cytosol, the second product of the reaction, malate, is taken up by the mitochondria. There it undergoes further transformations, mainly to succinate, which is the characteristic product of aspartate utilization. The details of this process will be described later.

It is noteworthy that in the transition phase the rate of ATP resynthesis by transphosphorylation and glycolysis is clearly lower than that of ATP consumption. This is indicated by a declining energy charge (Schöttler et al., 1984b). (The energy charge reflects the energetic state as represented by the energy available in the adenine nucleotide pool. It is defined as

$$
\mathrm{EC}=\frac{[\mathrm{ATP}]+0.5[\mathrm{ADP}]}{[\mathrm{AMP}]+[\mathrm{ADP}]+[\mathrm{ATP}]}
$$

In the body-wall of Arenicola it is 0.86 to 0.89 under normoxic conditions. The EC declines when utilization of ATP exceeds resynthesis.)

About three hours after the onset of hypoxia, the so-called switching phase begins. Characteristically, an increasing proportion of phosphoenolpyruvate (PEP), resulting from the degradation of glycogen, is then converted to oxaloacetate, and the phosphate group transferred to GDP (Fig. 2). Conversely, pyruvate formation declines to a corresponding extent, which results in decreased alanine accumulation. Concomitantly, utilization of phosphagen and aspartate gradually ceases as the concentrations of these substrates decline to low levels (Schöttler et al., 1984b).

The switching at the so-called PEP branchpoint is probably caused by a shift in the relative activities of pyruvate kinase and PEP carboxykinase which compete for the same substrate, PEP. Under aerobic conditions, PK prevails and pyruvate is the sole product. In hypoxia, the ratio of the two activities gradually changes at the expense of PK and eventually PEP is converted solely to oxaloacetate.

The role of PEPCK in the anaerobic degradation of glycogen has been convincingly demonstrated by Schöttler \& Wienhausen (1981), who inhibited the enzyme by means of 3-mercaptopicolinic acid. The inhibitory effect consisted not only of a striking decrease in the formation of metabolites derived from oxaloacetate (succinate, propionate and acetate; see below), but also of an accumulation of lactate, i. e. a metabolite was produced that in Arenicola normally does not occur in significant amounts. Evidently inhibiting PEPCK evoked the catalytic action of PK, transforming PEP to pyruvate as under aerobic conditions. It also indicates that other carboxylating enzymes such as pyruvate carboxylase are not involved in the formation of oxaloacetate.

A particularly important feature of the switching phase is the reduction of the metabolic rate (measured by the rate of ATP formation) to one fifth or less of the normal aerobic level (Schöttler et al., 1984b) as is shown in Table 1. As a consequence, the energy balance stabilizes as indicated by an (almost) invariable energy charge. Unquestionably, the dramatic drop in the metabolic rate is essential to the lugworms ability to survive several days of anoxia.

How the reduction of the metabolic rate is accomplished is not yet clear. Acidification of the tissues may be important in this respect. The intracellular $\mathrm{pH}$ was found to decline from 7.3 to 6.8 within 12 hours of experimental anoxia (and to 6.3 after 24 hours). 
Table 1. Metabolic rate and energy balance of Arenicola marina during normoxia and consecutive phases of hypoxia (modified from Schöttler, 1986, and * Kamp, 1992)

\begin{tabular}{|c|c|c|c|c|c|}
\hline & & & & $\%$ of total & \\
\hline & Glycogen & ATP & PTC & Glycolysis & $\begin{array}{l}\text { Succinate } \\
+ \text { vol. FA }\end{array}$ \\
\hline Normoxia & $<1.6^{\circ}$ & $60^{\circ}$ & & & \\
\hline Hypoxia & & & & & \\
\hline $0-3 \mathrm{~h}$ & $8.2^{*}$ & 40 & 23 & 59 & 18 \\
\hline $3-12 \mathrm{~h}$ & $2.2^{*}$ & 11 & 6 & 21 & 73 \\
\hline $12-24 \mathrm{~h}$ & $1.6^{\circ}$ & 9 & & & 100 \\
\hline $24-48 \mathrm{~h}$ & $1.4^{\circ}$ & 8 & & & 100 \\
\hline $\begin{array}{l}\text { Turnover: } \\
\text { by the res } \\
\text { were calcr } \\
\text { utilized, } \mathrm{n} \\
\text { volatile fat }\end{array}$ & $\begin{array}{l}\mathrm{g}^{-1} \text { d.w. } \mathrm{h} \\
\text { pathway (T) } \\
\text { from the qu } \\
\text { ic ATP turno } \\
\text { ds (propionat }\end{array}$ & $\begin{array}{l}f \text { total: } \\
\text { s of gly } \\
\text { s of an } \\
\text { m oxyg } \\
\text { etate) }\end{array}$ & $\begin{array}{l}\text { of co } \\
\text { radatic } \\
\text { d proc } \\
\text { i PTC }\end{array}$ & $\begin{array}{l}\text { ion to total r } \\
\text { ATP turnove } \\
\text { ccumulated } \\
\text { sphotaurocy }\end{array}$ & $\begin{array}{l}\text { thesis of } A T \\
\text { uring hypox } \\
\text { phosphage } \\
\text { ne; vol. FA }\end{array}$ \\
\hline
\end{tabular}

Although this clearly affected some processes (Kamp \& Juretschke, 1989a), it appears insufficient to account for the observed decline of the metabolic rate.

Nine to twelve hours after the onset of hypoxia, the switching from aerobic to anaerobic metabolism is complete. Malate is then the sole product of glycogen degradation. It does not accumulate in the cytosol; but is taken up by the mitochondria. In these organelles all subsequent reactions proceed which eventually result in the formation of the end products propionate and acetate (Zebe, 1975).

Malate is used as substrate by three different mitochondrial enzymes: malic enzyme, malate dehydrogenase and fumarase. The reactions which are catalysed by these enzymes not only occur simultaneously, although at different rates, but they interact with each other (Fig. 3). Some malate is converted to pyruvate by malic enzyme and this metabolite is subsequently oxidized to acetyl-CoA by pyruvate dehydrogenase. Another portion of malate undergoes reoxidation to oxaloacetate by malate dehydrogenase. Citrate synthase catalyses the formation of citrate from acetyl-CoA and oxaloacetate. Despite the absence of oxygen, citrate is degraded to succinyl-CoA.

The oxidative reactions can proceed, because the NADH arising is reoxidized. This is accomplished by converting a major portion of malate to fumarate in the reversed fumarase reaction. Fumarate functions as a hydrogen acceptor (instead of oxygen) and is reduced to succinate. Because some components of the respiratory chain are involved, succinate formation is coupled with ATP synthesis by oxidative phosphorylation.

The function of the mitochondria in the anaerobic metabolism of the lugworm has been elucidated by Schroff \& Schöttler (1977) who analysed the conversion of malate to succinate by isolated mitochondria. By inhibiting adenylate kinase, the authors succeeded in demonstrating the concomitant formation of ATP. Using arsenite and fluoroacetate to inhibit pyruvate dehydrogenase and isocitrate dehydrogenase, respectively, they found substantially decreased quantities of succinate, while the substrates of the inhibited enzymes, pyruvate or citrate, accumulated. These results indicate that the 


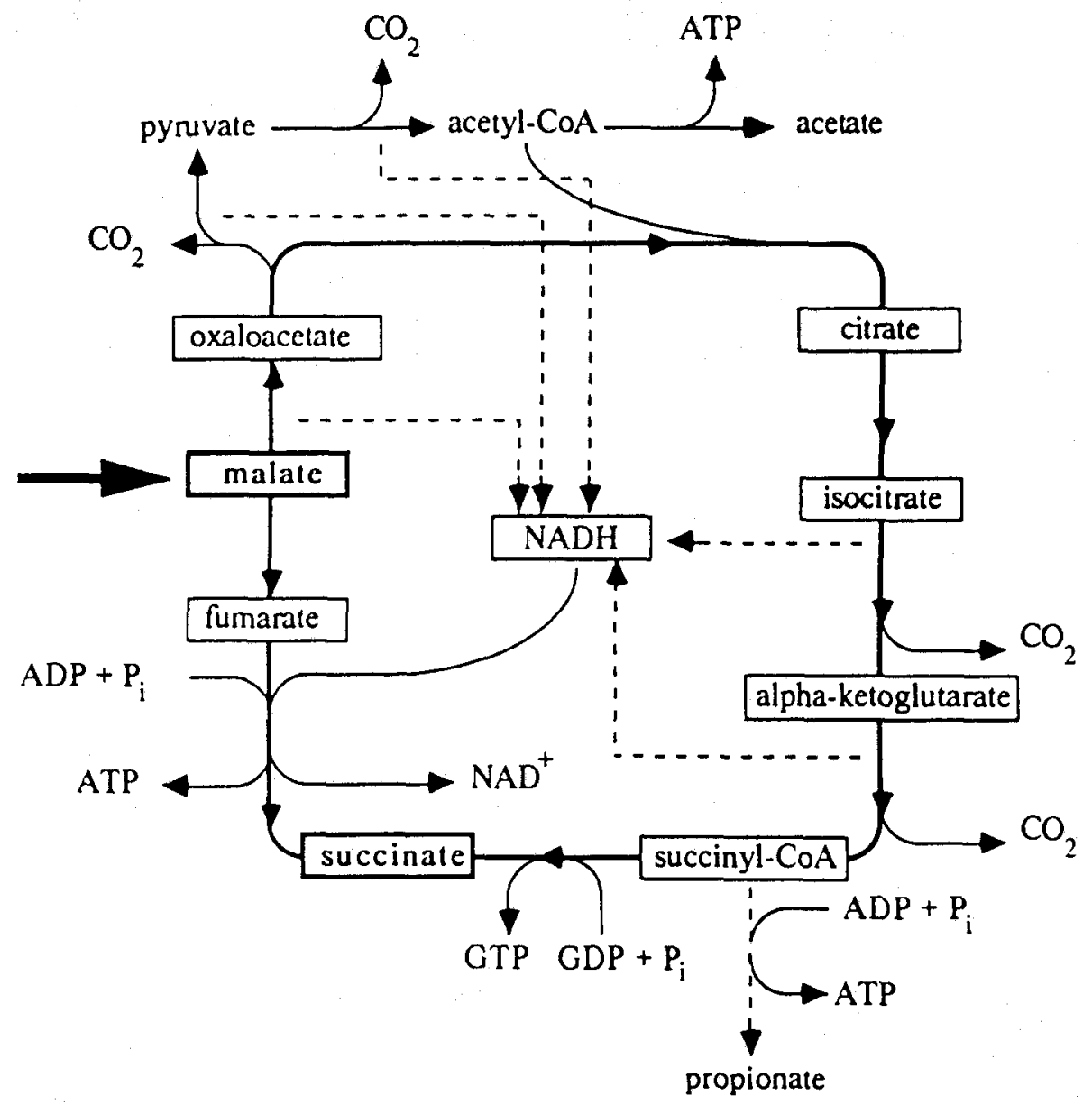

Fig. 3. Anaerobic metabolism of malate in mitochondria of body-wall tissue of Arenicola marina (from Schöttler \& Bennett, 1991)

first segment of the citric acid cycle is involved in the formation of succinate. They were also used to formulate the equations of the conversion of malate to succinate as follows:

$$
\begin{aligned}
& 2 \text { malate }+5 \mathrm{NAD}^{+} \longrightarrow \text { succinate }+5 \mathrm{NADH}+4 \mathrm{CO}_{2} \\
& 5 \text { malate }+5 \mathrm{NADH} \longrightarrow 5 \text { succinate }+5 \mathrm{NAD}^{+} \\
& \hline 7 \text { malate } \\
&
\end{aligned}
$$

The experiments revealed that in the presence of NADH even mitochondrial fragments are able to reduce fumarate to succinate. The reaction can be blocked by specific inhibitors of succinate-chinon-oxidoreductase (Fig. 4). This indicates that the so-called complexes I and II of the respiratory chain are involved.

Succinate is accumulated only in comparatively small quantities, because it is further transformed to succinyl-CoA in a first step which is followed by the conversion to methylmalonyl-CoA (Fig. 5). The next reaction, a decarboxylation, results in the forma- 


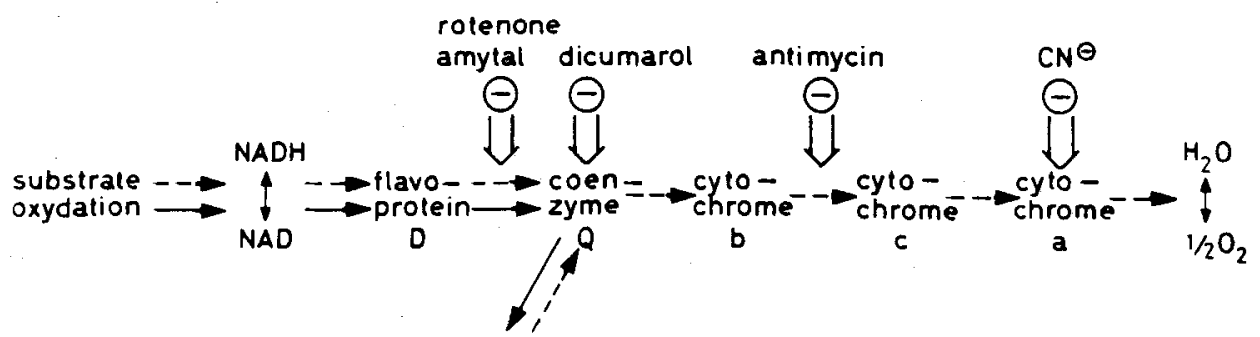

flavoprotein S

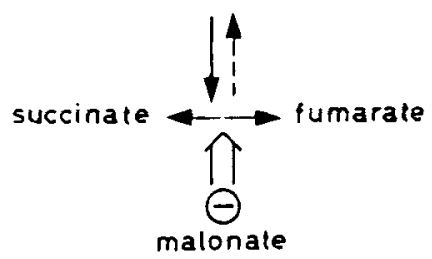

Fig. 4. Pathway of hydrogen in mitochondria of body-wall tissue of Arenicola marina (from Schroff \& Schöttler, 1977)

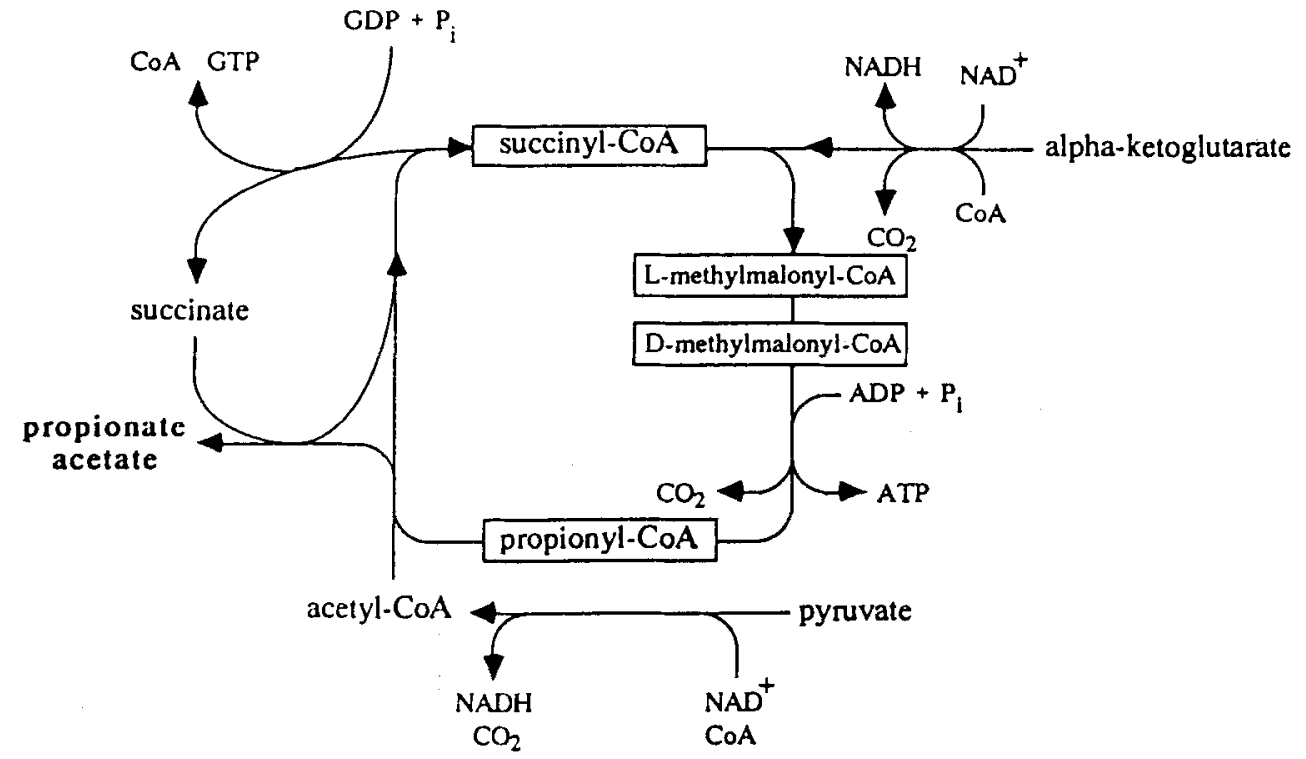

Fig. 5. Anaerobic formation of propionate and acetate in mitochondria of body-wall tissue of Arenicola marina (from Schöttler \& Bennett, 1991)

tion of propionyl-CoA and in the concomitant synthesis of ATP. In the final reaction of the pathway, propionate is split off, while CoA is transferred to succinate. This provides succinyl-CoA for another turn of the "succinate-propionate cycle". Propionate accumulates as an end product typical of anaerobic glycogen degradation.

The second end product, acetate, arises in an analogous way by the splitting of 
acetyl-CoA. Although in this case ATP likewise arises (Wienhausen, 1981), this is accomplished in a different manner (see below).

There is experimental evidence that isolated mitochondria retain the capability to convert succinate to propionate (Schroff \& Zebe, 1980). Maximal rates were observed, when malate and ADP were present in addition to succinate. The individual reactions of the pathway were demonstrated by employing labelled precursors. Schöttler (1983) identified all enzymes involved and analysed important details such as the role of the special transferase in the splitting of propionyl-CoA which makes possible the recycling of the energy-rich thioester bond and thus an efficient utilization of succinate in a continuous "succinate-propionate cycle".

Furthermore, investigating the formation of acetate in detail, Schöttler $(1980,1986)$ observed that it requires the presence of succinate in addition to acetyl-CoA. This seems to indicate that the splitting of acetyl-CoA is catalysed by the same CoA transferase which has a low specifity concerning the acyl moiety of its substrate. However, this would preclude a synthesis of ATP as found by Wienhausen (1981). But there seems to be another explanation of the apparently inconsistent results: succinyl-CoA produced by CoA transferase could be split by succinyl-CoA synthetase (succinyl-CoA $\rightarrow$ succinate + $\mathrm{CoA}+$ GTP) which would result in the synthesis of GTP. Since the rate of acetyl-CoA splitting has been found to increase, when succinyl-CoA synthetase was added to a suitable reaction mixture, and, on the other hand, inhibition of succinyl-CoA synthetase has the opposite effect, the presumption appears plausible.

In conclusion, it has to be pointed out that anaerobic glycogen degradation, resulting in the formation of succinate, propionate and acetate, yields 6 to 7 ATP (depending on the varying ratio propionate/acetate) as compared to 3 in the production of lactate. The fatty acids propionate and acetate, unlike lactate, easily permeate biological membranes and can thus be excreted into the ambient water. In this way, negative effects resulting from large-scale accumulation of metabolic end products such as acidosis and osmotic imbalance are avoided. This means, however, a loss of potentially energy-rich compounds.

Because of the long duration of the switching period, the formation of propionate and acetate starts rather slowly, so that the accumulation of these metabolites and, consequently, their excretion are delayed. Therefore, the appearance of volatile fatty acids in the water was evident only after 6 hours of experimental anoxia (Surholt, 1977a, b; Schöttler et al., 1984b; Holst \& Zebe, 1986). Since low tide in the natural habitat usually lasts about 6 hours, the release of propionate and acetate then would be insignificant. This has been confirmed by analysing lugworms immediately after their removal from the burrows. Individuals obtained after maximal periods of emersion (6 to 8 hours) had accumulated comparatively large quantities of succinate, whereas the concentrations of propionate and acetate were only slightly increased (Pionetti \& Toulmond, 1980; Schöttler et al., 1984a). Obviously, large-scale release of volatile fatty acids, as observed during long periods of experimental anoxia (Surholt, 1977a, b; Schöttler et al., 1984b; Holst \& Zebe, 1986), occurs very rarely, e.g. during extreme periods of emersion.

Experiments conducted to investigate the details of the release have revealed that it is not affected by the occlusion of the anus or by preventing gill function by ligations (Holst \& Zebe, 1986). Since the excretory activity of the nephridia is reduced in hypoxia, only insignificant amounts of volatile fatty acids can be excreted by the way of urine. Therefore, it is very likely that propionate and acetate are mainly released from the body- 
wall of the lugworm. The percentage of propionate appearing in the water regularly exceeded that of acetate which also accumulated in comparatively small quantities.

The rate of fatty acid release was shown to depend on the concentration gradient between lugworm and water. This suggests that it proceeds by diffusion. However, when animals were injected with butyrate, this caused a substantial reduction of propionate excretion. From the inhibitory effect, it appears that carrier molecules could mediate the release.

In view of its ecophysiology, the ability of the lugworm to maintain an aerobic metabolism at reduced $\mathrm{pO}_{2}$ was tested to determine the precise limit at which the first symptoms of hypoxia appear. In experiments conducted by incubating animals 24 hours at various controlled low-oxygen levels, the concentrations of phosphagen, aspartate, alanine and succinate started changing at a $\mathrm{pO}_{2}$ of 45 Torr (Schöttler et al., 1983). At first, the changes were detected in the gut/chloragogen tissue complex, whereas in the bodywall they occurred between 37 and 20 Torr. Very likely, this difference is due to differences in the oxygen supply to these organs as well as in the concentrations of some metabolites, including phosphagen, whose concentration in the gut is minimal. At 15 Torr, the metabolism was completely anaerobic as indicated by the finding that the quantity of accumulated end products was the same as in full anoxia.

In lugworms incubated at 22 Torr, symptoms of an anaerobic metabolism were evident after one hour; but after 12 hours the extent to which metabolite levels had changed was still clearly less than after 12 hours of anoxia, indicating a partially aerobic metabolism.

Periods of hypoxia lasting several hours mean severe stress to an organism because of the resulting high demand for stored reserves. In addition, reducing the metabolic rate to less than $20 \%$ of the normal rate requires that all functions are decreased to the minimum necessary to secure survival. In view of these dramatic curtailments, it is particulary important to the lugworm to re-establish aerobic metabolism as soon as the tide rises and oxygen-rich water becomes available again. Likewise, normal functions have to be quickly restored to their optimal levels. Subsequently, accumulated metabolites must be removed and utilized reserves replenished. All these processes are typical of the so-called recovery phase.

Studying lugworms during their recovery from 24 hours of experimental anoxia revealed a characteristic pattern of the different processes involved (Pörtner et al., 1979; Schöttler 1983, 1986). As soon as oxygen became available again, the concentrations of adenine nucleotides started changing, and the levels typical of normoxia were restored within 2 hours. Resynthesis of phosphagen was also resumed quickly, but it took 3 to 4 hours to fully replenish the store. The amounts of accumulated succinate and propionate were reduced by half after 30 minutes, but subsequently the degradation of these substances proceeded only slowly, probably due to the fact that a large proportion was in the body-fluids and had to be taken up by the tissues. Removal of accumulated alanine from the coelomic fluid required more than 10 hours, whereas utilized aspartate was resynthesized within 5 hours. Glycogen reserves were only partially replenished, probably because of an insufficient supply from the digestive system of the animals after several days of starvation. Nevertheless, some gluconeogenesis was evident in gut/ chloragogen tissue and so was the release of glucose from the cells. These findings suggest a role of this organ in supplying other tissues with substrate(s). 
Altogether, these results indicate that a fully aerobic metabolism is restored within 60 minutes after readmission of oxygen, and possibly much earlier. It is likely that within this period all functions are also elevated to their optimal rates. Removal of the metabolites accumulated during 24 hours of anoxia (a rare event under natural conditions!) takes much longer, which, however, does not seem to affect vital processes.

It is not known whether in the initial phases of recovery the total metabolic rate rises above the normal aerobic level, resulting in an increased oxygen uptake. Attempts to determine whether there was an oxygen debt in Abarenicola pacifica after 3 days of anoxia did not show unequivocal results (May, 1972).

Rapid recovery depends on the resumption of the normal pumping activity by the lugworm as soon as the tide rises. How does the animal become aware of the presence of oxygen-rich water? There is evidence that the caudal end of Arenicola (which is usually kept in a position close to the surface of the sediment) is highly sensitive to changes of the $\mathrm{pO}_{2}$. (Toulmond et al., 1984; Dejours \& Toulmond, 1988). Obviously, special chemoreceptors present there are stimulated and, via a pacemaker in the central nervous system, control the pumping activity.

Occasionally, the lugworm is also likely to encounter so-called function-related anaerobiosis in addition to the regular periods of hypoxia at low tide. This stems from excessive muscle activity, as is required when the worm after having been exposed at the surface must rapidly re-dig into the sediment. In such a situation, ATP is mainly resynthesized by transphosphorylation from phosphagen. In addition, anaerobic glycolysis is initiated as well as utilization of aspartate (Siegmund et al., 1985), which typically results in the accumulation of alanopine and succinate together with small amounts of malate. This is similar to the changes observed in the transition phase after the onset of environmental anaerobiosis, except that strombine is then formed instead of alanopine.

Physiological conditions in functional and environmental anaerobiosis differ substantially with respect to the glycolytic rate, i.e. the quantity of pyruvate produced during a certain period of time. Kreutzer et al. (1989) postulated from theoretical considerations that at low glycolytic rates (characteristic of environmental anaerobiosis) the amino acid present in the highest concentration should be preferentially used as substrate in the condensation reaction. Since this is glycine in Arenicola, it would favour formation of strombine. On the other hand at high glycolytic rates (as they occur in working muscles), when comparatively large amounts of pyruvate are produced, the most active enzyme present would determine its transformation. Since alanopine dehydrogenase exceeds strombine dehydrogenase by a factor of 10, alanopine should arise as the predominant end product in functional anaerobiosis. The results of comparative analyses using 25 different species of marine invertebrates have fully confirmed this hypothesis (Kreutzer et al., 1989).

In view of the frequent switching of the lugworm between aerobic and anaerobic metabolism, the mechanisms of metabolic control involved are particularly interesting. In this context, the special properties of two important regulatory enzymes have been analysed.

By catalyzing the degradation of glycogen, glycogen phosphorylase (GP) determines the glycolytic flux. Therefore, regulation of its activity is a fundamental feature of anaerobic metabolism. The lugworm enzyme seems to be controlled in a manner different from the phosphorylation/dephosphorylation mechanism present in vertebrate skeletal muscle (which may encounter functional anaerobiosis). In the body-wall the 
degree of GP phosphorylation did not change significantly after various periods of hypoxia, although the rate of glycogenolysis increased substantially (Kamp, 1986; Hunfeld \& Kamp, 1990). In vitro phosphorylation of (unphosphorylated) GP b was achieved by employing rabbit phosphorylase kinase (Kamp \& Winnemöller, 1992). As it turned out, phosphorylation was then not complete, but evidently had resulted in the formation of a hybrid form composed of one phosphorylated and one unphosphorylated subunit. It was designated GP a/b (Kamp \& Winnemöller, 1992). A completely phosphorylated enzyme has not been obtained in vitro nor was it detected in vivo.

In the body-wall musculature of the lugworm, $G P$ a/b is the predominant form. Its catalytic activity was shown in vitro to depend on the concentrations of inorganic phosphate and AMP (Kamp, 1986). According to Kamp (1992), it is very likely that in vivo GP a/b activity is also regulated by phosphate and AMP. (The affinity of this form for both compounds clearly exceeds that of GP b.). Under normoxic conditions, the levels of phosphate and AMP in the tissues (as calculated from ${ }^{31} \mathrm{P}$-NMR data) are very low., i.e. too low to activate GP a/b. After the onset of hypoxia, the concentration of phosphate rises substantially (due to the utilization of phosphagen), which results in the activation of GP a/b. The increase of AMP has a supporting effect (Kamp, 1992). According to the results of Kamp and coworkers, other regulatory mechanisms appear insignificant for controlling GP activity in the body-wall of Arenicola. In this respect, another observation is important: the activity of glycogen synthase of the lugworm also depends on the concentration of phosphate, but is affected in a different way, as an increase causes inhibition (Hunfeld \& Kamp, 1990). Possibly, an interrelation exists between the control of phosphorylase and glycogen synthase, as has been demonstrated in vertebrates.

Pyruvate kinase has a central role in anaerobic metabolism, because it is essential to the switching at the PEP branch-point. Its activity must change to a great extent and in a precisely controlled manner. Under normoxic conditions, the glycolytic flux is at a minimum and, consequently, PK activity very low. After the onset of hypoxia, however, large quantities of metabolites derived from pyruvate accumulate, indicating a substantially increased glycolytic rate and a correspondingly high PK activity. When anaerobiosis continues for several hours, pyruvate formation gradually declines, until it ceases completely and the switching becomes fully effective.

From the few existing studies on lugworm PK, it appears that the enzyme may be regulated in various ways. Analyses of the kinetics of PK reaction have shown an influence of certain effectors (Englisch, 1989). This may suggest that the rise of PK activity in the early phase of anaerobiosis could result from allosteric effects of changing concentrations of phosphotaurocyamin as well as of fructose-1,6-bisphosphate. While the inhibitory effect of the former declines as the phosphagen is degraded, a rising level of the latter causes an activation.

There is evidence, however, that further regulatory mechanisms exist which effectively regulate PK action by changing its affinity for PEP. As the results of Schöttler (1980) and Englisch (1989) indicate, the affinity clearly declines during anaerobiosis. This seems to be due to some extent to the decreasing $\mathrm{pH}$, but in addition, modifications of the molecular structure of PK may be involved which augment this effect.

According to the investigations of Englisch (1989), the following structural alterations could be involved: 
(1) Phosphorylation/dephosphorylation: the affinity for PEP of PK extracted from lugworms subjected to anoxia was shown to increase by treatment with phosphatase. Analyses of purified Arenicola PK by isoelectric focussing revealed that the enzyme is not homogenous. At least five discrete bands containing enzymatic activity have been observed which may represent different degrees or stages of phosphorylation. It was impossible, however, to detect quantitative differences between the band patterns of normoxic specimens and those exposed to anoxia.

(2) Changes by aggregation or dissociation of subunits of the enzyme molecule: According to gel filtration analyses, PK may occur (in vitro!) in forms which differ with respect to molecular mass, i.e. in the number of subunits.

(3) Changes in the association of PK with structural elements of the cell: In normoxic lugworms, PK appears to be mainly associated with cellular particles, while during anaerobiosis the extent of association declines.

Thus far, it has not been possible to isolate and characterize different forms of PK in Arenicola. The significance of the various alterations of its molecular structure remains unsolved. It seems, however, that in the lugworm the regulation of $\mathrm{PK}$ is highly complex.

In conclusion, it should be stated that, until now, there is no indication of a change of PEPCK activity with respect to the switching from aerobiosis to anaerobiosis.

\section{INFLUENCE OF HYDROGEN SULFIDE}

The anoxic sediment of the tidal zone is rich in sulfides including free hydrogen sulfide. In the interstitial water, the concentration of the latter may be as high as $1 \mathrm{mmol}$ - $\mathrm{l}^{-1}$ (Groenendaal, 1979; Völkel \& Grieshaber, 1992). $\mathrm{H}_{2} \mathrm{~S}$ is extremely toxic, because it inhibits cytochrome $c$ oxidase (although reversibly) and thus prevents aerobic metabolism. In recent years, it has become evident, however, that many animals are tolerant of $\mathrm{H}_{2} \mathrm{~S}$, at least to some degree, and hence are able to live in $\mathrm{H}_{2} \mathrm{~S}$ environments, including the tidal zone (Vismann, 1991; Giere, 1992). Therefore, the question arises: How does $\mathrm{H}_{2} \mathrm{~S}$ affect the lugworm? What adaptations allow it to cope with this important ecofactor?

Ecological studies in the Dutch Wadden Sea have revealed that $\mathrm{H}_{2} \mathrm{~S}$ has an obvious influence on Arenicola: The population density was found to be inversely related to the $\mathrm{H}_{2} \mathrm{~S}$ concentration at the depth of the burrows (Groenendaal, 1979).

In laboratory experiments, lugworms survived about 90 hours of incubation in oxygen-free seawater to which sulfide $\left(10 \mathrm{mmol} \cdot \mathrm{l}^{-1}\right)$ had been added $\left(10^{\circ} \mathrm{C}\right.$; Groenendaal, 1980, 1981). It was found that $\mathrm{H}_{2} \mathrm{~S}$ rapidly penetrated into the tissues, until an equilibrium between the external and internal concentrations was reached. Typically, the latter was only 50 percent (or even less) of the former, which is due to the fact that the internal $\mathrm{pH}$ is maintained 0.2 units below that of the medium. As a consequence, the concentration of undissociated $\mathrm{H}_{2} \mathrm{~S}$ rises within the body and thus favours its outward diffusion. Under anoxic conditions, no fundamental chemical changes of sulfide occurred nor was it bound by components within the lugworms body.

When oxygen is present, however, the lugworm evidently has the capability of oxidizing $\mathrm{H}_{2} \mathrm{~S}$, i.e. there is a detoxification. Völkel \& Grieshaber (1992) have shown that the internal $\mathrm{H}_{2} \mathrm{~S}$ concentration then remains very low, while thiosulfate accumulates in the coelomic fluid. When the external concentration of $\mathrm{H}_{2} \mathrm{~S}$ was raised, the rate of its penetration into the body increased. Eventually, the oxidation capacity became insuffi- 
cient as indicated by rising internal $\mathrm{H}_{2} \mathrm{~S}$ concentration. As a result, cytochrome c oxidase was inhibited and the lugworm had to resort to anaerobic metabolism initiating the accumulation of succinate.

In a detailed study, Völkel \& Grieshaber (1994) tested the capacity of $\mathrm{H}_{2} \mathrm{~S}$ oxidation. They found that under normoxic conditions the limit was an external $\mathrm{H}_{2} \mathrm{~S}$ concentration of approximately $0.3 \mathrm{mmol} \cdot 1^{-1}$. When lugworms were incubated in water containing higher $\mathrm{H}_{2} \mathrm{~S}$ concentrations, the internal $\mathrm{H}_{2} \mathrm{~S}$ level rose to $0.5 \mathrm{mmol}$ or even higher (depending on the season, i.e. the physiological state of the animals). This resulted in an inhibition of the aerobic metabolism as indicated by a rising succinate concentration. When the authors increased the external sulfide from 0.76 to $1.27 \mathrm{mmol} \cdot 1^{-1}, \mathrm{H}_{2} \mathrm{~S}$ in the coelomic fluid did not increase as expected, but did not change significantly. Therefore, they assume that another mode of sulfide detoxification might exist in addition to thiosulfate formation.

A rise of the internal $\mathrm{H}_{2} \mathrm{~S}$ concentration was also observed when the $\mathrm{pO}_{2}$ of the ambient water declined. Obviously, the capacity of $\mathrm{H}_{2} \mathrm{~S}$ oxidation declined substantially as soon as the high demand for oxygen was not met.

Thiosulfate was shown to be the main product of sulfide oxidation. In lugworms incubated for 8 hours at $1 \mathrm{mmol} \cdot \mathrm{l}^{-1} \mathrm{H}_{2} \mathrm{~S}$, its level rose almost linearly with time to about $4 \mathrm{mmol} \cdot \mathrm{l}^{-1}$. In addition, sulfite $\left(0.04 \mathrm{mmol} \cdot \mathrm{l}^{-1}\right)$ appeared as a minor oxidation product, but no sulfate was detected.

Sulfide oxidation proceeds in the mitochondria. Studying the oxygen uptake of mitochondria prepared from body-wall tissue, Völkel \& Grieshaber (1994) demonstrated a dramatic increase in the respiratory rate upon adding $\mathrm{H}_{2} \mathrm{~S}$ to the incubation mixture. Oxygen consumption was then similar to that observed with succinate plus ADP. Sulfiderelated oxygen uptake, however, proved to be independent of ADP. A stoichiometric ratio sulfide to oxygen to thiosulfate $1: 1: 0.5$ was measured. Sulfide-related oxygen uptake was shown to be inhibited by cyanide and azide (the inhibitory effect of KCN exceeding that of azide), but the inhibition was not complete and, in addition, it was clearly less than in the case of succinate oxidation. Even when succinate respiration was completely inhibited, oxygen uptake could still be stimulated by sulfide. This result suggests that different enzymes may be responsible for succinate and sulfide oxidation, respectively. Völkel \& Grieshaber (1994) propose that an alternative terminal oxidase be present in lugworm mitochondria which is not inhibited by high $\mathrm{H}_{2} \mathrm{~S}$ concentrations and which has a lower sensitivity towards cyanide and azide than cytochrome coxidase. The important question, whether sulfide oxidation in lugworm mitochondria is coupled with the synthesis of ATP, cannot yet be answered.

The presence of an active component in the blood of Arenicola which catalyzes the oxidation of sulfide has been reported by Patel \& Spencer (1963). According to these authors, it is an oxidized derivative of hemoglobin, the so-called brown pigment. Studying the blood of the related species A. affinis, Wells \& Pankhurst (1980) failed to detect any brown pigment. They found that $\mathrm{H}_{2} \mathrm{~S}$ did not affect the affinity of hemoglobin for oxygen or any other properties relevant to the capacity of oxygen transport. In this respect, lugworm hemoglobin markedly differs from vertebrate hemoglobin. 


\section{OSMOREGULATION}

The salinity of the water which, at low tide, remains in the tidal zone may change considerably, depending on weather conditions. Although lugworms stay in their burrows, they are affected by the osmotic instability of the environment. When the salinity of the ambient water changes, this induces corresponding changes of the osmotic values of the body fluids as well as of the cells. While the lugworm responds in an osmoconform manner, it is tolerant of the fluctuations normally occurring in its habitat.

As previous investigations have shown, the composition of the coelomic fluid (which represents about $50 \%$ of the total body volume) is very similar to that of seawater, except that it contains small amounts of organic compounds in addition to anorganic ions and is slightly hyperosmotic (Robertson, 1949; Oglesby, 1973; Shumway \& Davenport, 1977). In contrast, the concentration of anorganic ions is comparatively low in the cells, whereas that of organic molecules is high. Typically, certain amino-acids are the most important osmolytes with respect to their quantity (Abbott \& Awapara, 1961; DuchateauBoisson et al., 1961; Florkin \& Schoffeniels, 1965; Clark, 1968a, b). When the salinity in the ambient water declines, this causes a striking reduction in the concentrations of glycine, L-alanine and D-alanine, i.e. of those amino-acids which, at a salinity of $32 \%$, together contribute about $85 \%$ to the total content of free amino-acids in the cells (Felbeck, 1980).

Investigating the response of the lugworm to a sudden change of the salinity, Reitze \& Schöttler (1989) monitored various parameters over several days after placing specimens in diluted seawater. This "hypoosmotic shock" evoked a striking increase in the body volume (or weight) which exhibited a characteristic time course. At first, it was rather rapid, but gradually became slower. After attaining a maximum, the body volume started to decrease slowly. Eventually, it stabilized at a level clearly higher than that prior to the experiment. The extent of the volume change and the duration of the different phases increased with increasing dilution of the seawater, i.e. with the magnitude of the hypoosmotic shock (Fig. 6). In lugworms transferred to $50 \%$ seawater, the volume increased to $130 \%$ initially and stabilized at $110 \%$ after a period between 36 and 48 hours. The data indicate that the hypoosmotic shock evokes a phase of water uptake due to the osmotic imbalance between the lugworm and the ambient medium. But this induces an active regulation by the animal which eventually results in establishing a new balance at an increased body volume. Evidently, the increase observed was considerably less than that of an osmotic cell swelling passively under identical conditions. Since the body volume typical of undiluted seawater is not completely restored, the regulation may be considered imperfect.

In parallel experiments, Reitze \& Schöttler (1989) also measured the changes of osmotic value of the coelomic fluid induced by hypoosmotic shock. As Figure 6 shows, there was a rapid decrease initially which gradually slowed down later-on. Eventually, a new constant value was attained which was regularly 10 to $12 \mathrm{mosm} \cdot \mathrm{kg}^{-1}$ higher than that of the ambient medium.

The hypoosmotic shock induced volume changes in the body-wall tissue which were even larger than those of the whole body (Fig. 7). The maximum observed in $50 \%$ seawater was $210 \%$ (as compared to $130 \%$ in the intact lugworm). The time-course was similar to that of the whole body except that the changes proceeded at a much slower 


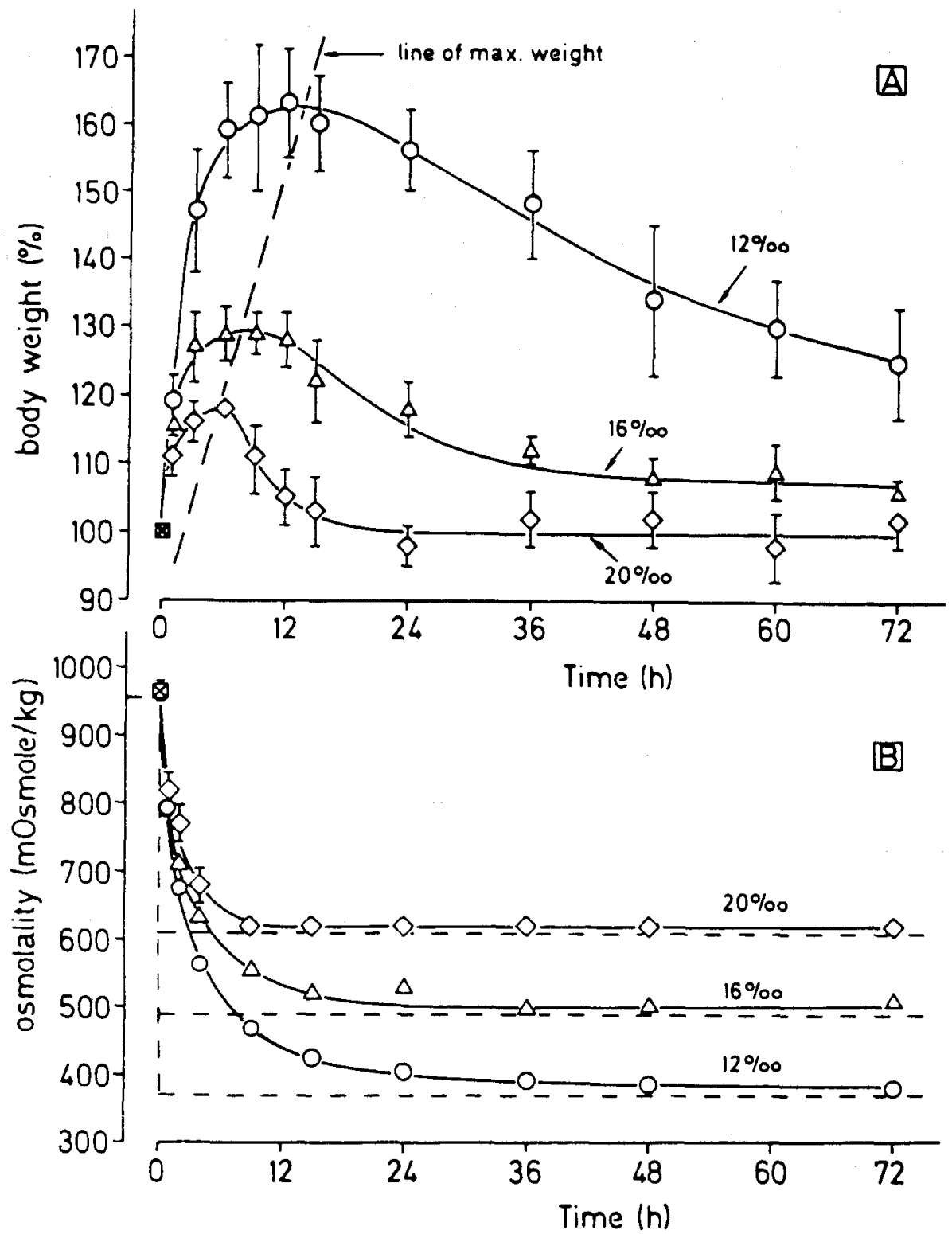

Fig. 6. Response of Arenicola marina to hypoosmotic shock (transfer from $32 \%$ salinity to 20,16 or $12 \%$, respectively): A: Change of weight; $\mathrm{B}$ : Change of the osmotic value of coelomic fluid (from Reitze \& Schöttler, 1989). Mean values $\pm S D, n=4,15$ individuals per vessel

pace: e. g. in $50 \%$ seawater it took more than 144 hours to stabilize the tissue volume at $170 \%$ of that in undiluted seawater.

Concomitant measurements of the concentrations of glycine, alanine, taurine, glutamate and aspartate in the body-wall revealed that these amino-acids changed in a 


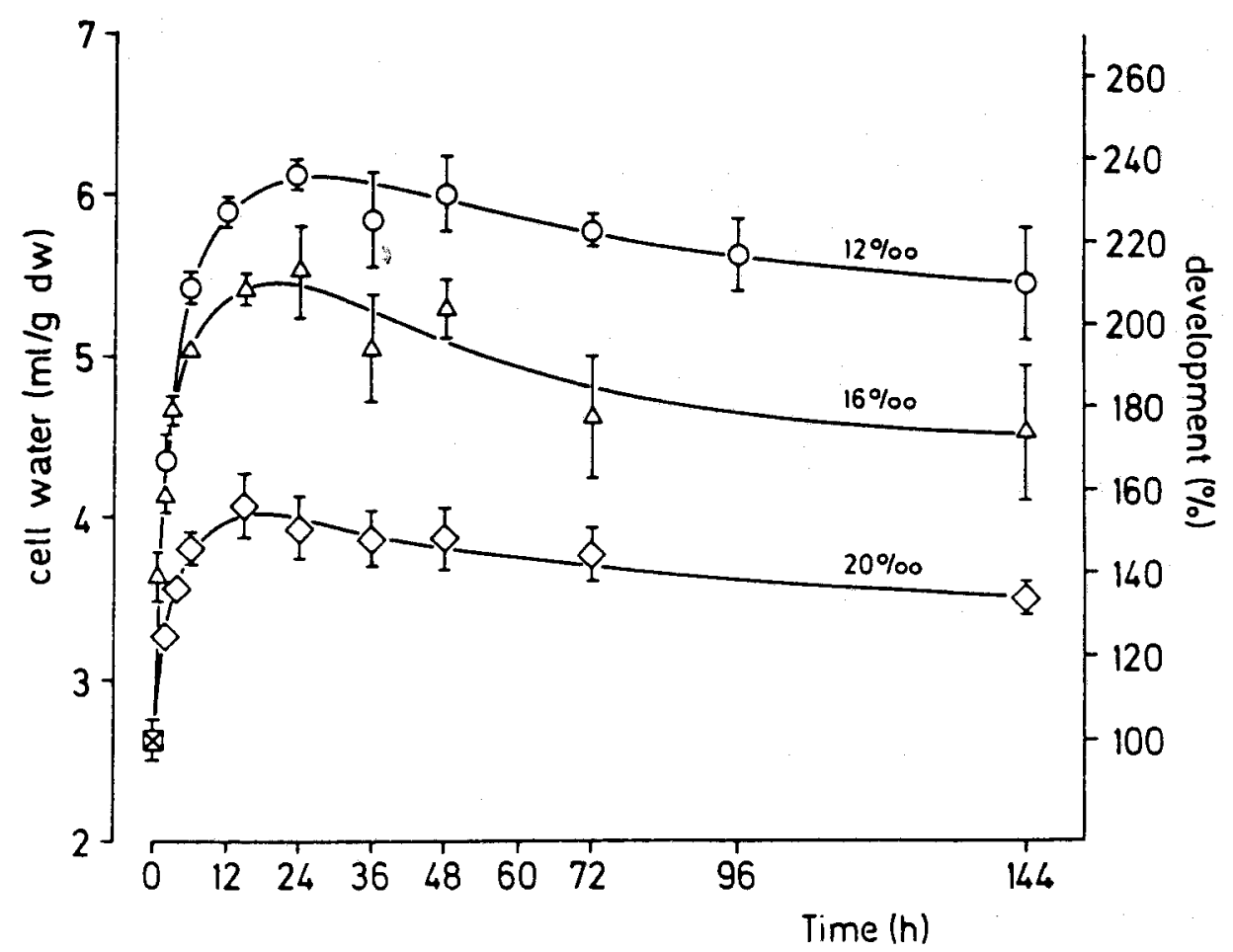

Fig. 7. Response of Arenicola marina to hypoosmotic shock: Change of cellular water content (from Reitze \& Schöttler, 1989). Mean values \pm SD, $n=4$

strikingly variable manner (Fig. 8). After incubating lugworms for 72 hours in $50 \%$ seawater, the contents of glycine and alanine decreased by $40 \%$ and $60 \%$, respectively, whereas that of taurine was unchanged in relation to the dry weight. On the other hand, glutamate increased slightly, and aspartate more than twofold.

There is evidence that glycine and alanine were utilized in catabolic metabolism: there was a marked increase in the concentration of ammonia in the coelomic fluid as
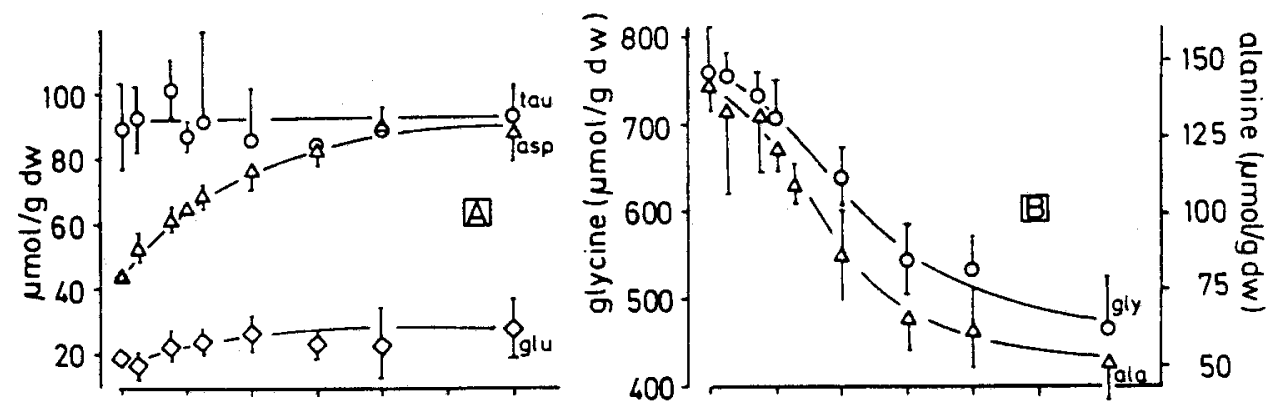

Fig. 8. Response of Arenicola marina to hypoosmotic shock (transfer from $32 \%$ salinity to $16 \%$ ): Change of amino acid content in body-wall tissue in relation to dry weight. Mean values $\pm \mathrm{SD}$, $\mathrm{n}=4 ;$ ala = alanine; asp = aspartate; glu = glutamate; $g l y=$ glycine $;$ tau $=$ taurine 
well as in the quantity of ammonia released into the water (Fig. 9). Degradation of amino acids was also demonstrated directly by applying labelled glycine or alanine. In $50 \%$ seawater, lugworms excreted much more ${ }^{14} \mathrm{CO}_{2}$ than in undiluted seawater.

During the period of volume regulation, oxygen consumption almost doubled (Fig. 10). Since the levels of various metabolites either remained constant or changed only slightly, it appears that there was no significant change in metabolism. The energy charge also decreased very little.

The role of the amino acids in volume reduction of the body-wall tissue was demonstrated by injecting lugworms with the transaminase inhibitor, aminooxyacetate, three hours prior to transferring them to diluted seawater. In this case, the contents of the amino acids did not change and, as a consequence, the animals failed to reduce their volume after this had increased to a maximum following the hypoosmotic shock, i.e. the inhibitor had prevented volume regulation.

In conclusion, it has to be stressed that the results described disprove the idea of osmoconformity being solely based on passive adjustments following the disturbance of osmotic balance. They clearly indicate that volume regulation already starts long before the osmotic balance is restored.

It appears that osmoregulation in the lugworm is accomplished by two distinct and independent mechanisms: one extracellular and one intracellular. This has to be concluded from the observation that the total body volume was already at its maximum,

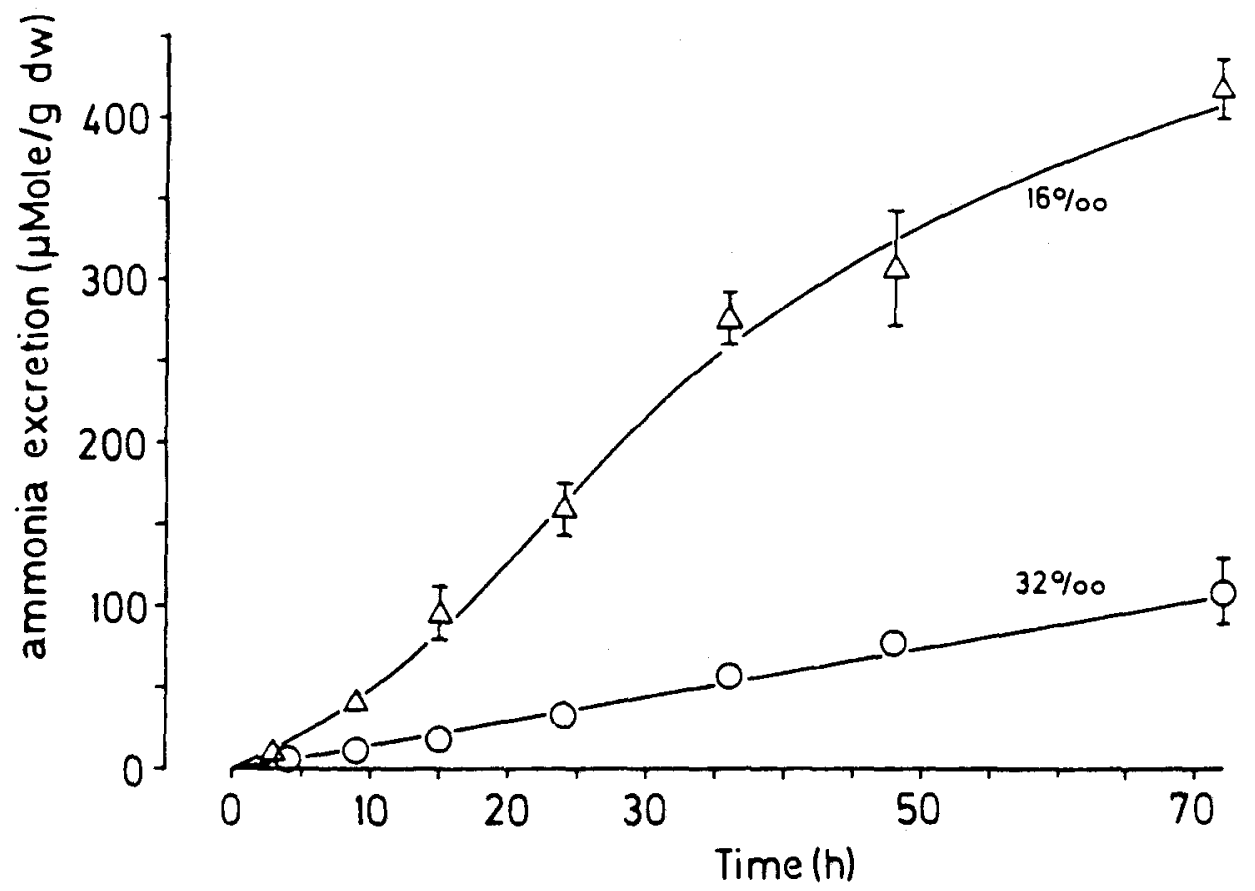

Fig. 9. Response of Arenicola marina to hypoosmotic shock (transfer from $32 \%$ salinity to $16 \%$ ): excretion of ammonia (from Reitze \& Schöttler, 1989). Mean values $\pm S D, n=4,15$ individuals per vessel 


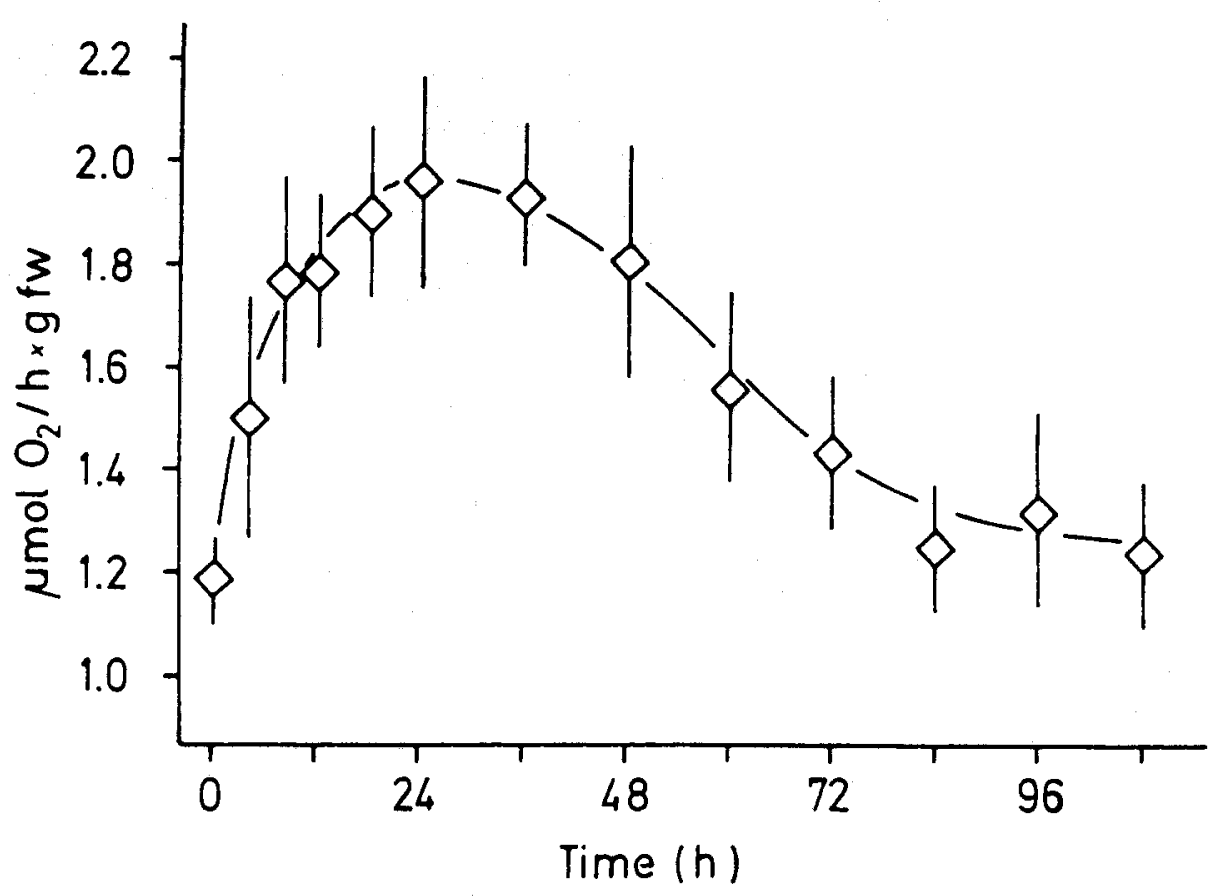

Fig. 10. Response of Arenicola marina hypoosmotic shock (transfer from $32 \%$ salinity to $16 \%$ ): oxygen uptake (from Reitze \& Schöttler, 1989). Mean values $\pm S D, n=6,4$ individuals per vessel

while the volume of the cells in body-wall tissue still increased. As a consequence, a shifting of water from the extracellular compartment to the tissues occurred. This confirms previous results which had shown that Arenicola, while adapting to reduced salinity, takes up relatively more water into the tissues than into the coelomic fluid (Freeman \& Shuttleworth, 1977a, b).

Extracellular volume regulation is probably based on a variation of the rate of urine production. After being transferred to a hypoosmotic environment, the lugworm will take up water due to the osmotic gradient. Because of the swelling of the body, the internal hydrostatic pressure rises which results in an increased rate of urine production by the nephridia.

Intracellular volume regulation is effected by changing amino acid concentrations, glycine and alanine in particular, in the cytoplasm. The decline of the osmotic value observed after a hypoosmotic shock, however, was clearly larger than could be attributed to the reduced concentration of amino acids. Therefore, Reitze \& Schöttler (1989) presume that an additional mechanism, still unkown, might be involved in the intracellular volume regulation in the body-wall of Arenicola.

The increased release of ammonia and $\mathrm{CO}_{2}$ demonstrating the degradation and transformation of glycine and alanine in response to a hypoosmotic shock is catalyzed by pyridoxal enzymes such as transaminases, especially alanine aminotransferase, and racemases, as can be inferred from the effect of aminooxyacetate, a specific inhibitor of 
these enzymes (Reitze et al., 1989). The release of ammonia, very likely, results from the deamination of glutamate by glutamate dehydrogenase (Batrel \& Gal, 1984; Reitze et al., 1989). Neither the purine nucleotide cycle (as postulated by Gibbs \& Bishop, 1977) nor amino acid oxidases, alanine dehydrogenase or alanine decarboxylase seem to be involved.

When lugworms are placed in a hyperosmotic medium such as $47 \%$ seawater, they lose water passively due to the osmotic gradient (Schiedek \& Schöttler, 1990b): after $24 \mathrm{~h}$ their weight is reduced by $30 \%$. Only after attaining a new osmotic balance do the animals slowly regain weight. This uptake of water results from intracellular volume regulation and a rise in the concentrations of glycine and alanine, the increase of the latter being relatively larger than that of the former (Schiedek \& Schöttler, 1990b). The adaptation of the lugworm to hyperosmotic conditions proceeds rather slowly as it requires 7 to 10 days after transferring animals from 32 to $47 \%$.

In the natural environment of the lugworm, salinity will never change as it did in the experiments described. Although the results obtained represent extremes, they illustrate clearly the physiological processes involved. In this respect some observations of Shumway \& Davenport (1977) seem particularly revealing. These authors exposed lugworms to salinity changes as they may occur in estuaries. They found that the animals retreated to the deepest parts of the (artificial) burrows when they came into contact with hypoosmotic water and remained there in an immobile state. As soon as normal salinity was restored, they resumed their usual activity. The osmotic value of the coelomic fluid as well as the amino acid concentrations in the body-wall were found to change, however, only in lugworms placed in glass tubes without sand, whereas no changes occurred in those burrowed in sand. Obviously, the latter were rather well protected from fluctuations in the overlying water.

Reitze \& Schöttler (1989) have observed that after heavy rains, during low tide, lugworms occasionally started swelling and subsequently again reduced their volume. In these cases, the amino acid concentration in the body-wall did not change. Presumably, this happens only during long-term (i.e. seasonal) salinity changes.

Since Arenicola also inhabits the western part of the Baltic where the salinity may be lower than $10 \%$, the specimens living there should have greatly reduced amino acid concentrations in comparison to those of North Sea populations. Preliminary data obtained from specimens collected in the Wismar Bay indicate that this is indeed the case. In the body-wall, 300-400 $\mu \mathrm{mol} \cdot \mathrm{g}^{-1}$ dry weight were measured (as compared to about $1000 \mathrm{umol} \cdot \mathrm{g}^{-1} \mathrm{~d}$.w. in the North Sea). Furthermore, Baltic lugworms have been shown to survive even at $6 \%$ salinity, while their intracellular amino acid level declined to extremely low values (Schiedek, unpublished results). This clearly indicates an adaptation to the brackish environment.

\section{MULTI-FACTOR ANALYSES}

In their natural habitat, lugworms are likely to be exposed to the combined effects of various ecofactors. Such complex conditions have been studied recently by multi-factor analyses. When the salinity of the water was reduced in the absence of oxygen, this caused a drastic decrease of the survival period (Schöttler et al, 1990). Although the metabolic rate initially clearly increased, indicating a high demand for energy resulting 
from osmoregulation, and subsequently declined as it usually does, there was only a limited reduction of the extracellular volume, while the concentration of the amino acids in the body-wall did not change, i.e. intracellular volume regulation was blocked. Obviously, the regulatory capacity of the animals did not suffice to overcome the combined effects of anaerobiosis and osmotic imbalance.

In another series of experiments, the influence of temperature (which, after emersion, is particularly variable in the sediments of the tidal zone) on anaerobic metabolism was studied. The results indicate that in specimens obtained in May the survival period did not change between 0 and $12^{\circ} \mathrm{C}$. At $16^{\circ} \mathrm{C}$, the animals likewise survived 72 hours of anoxia, but their energy charge was then substantially lower (indicating a more severe stress). At $20^{\circ} \mathrm{C}$ they survived only 36 hours of anoxia as the energy charge had declined below 0.5. Concomitant analyses of metabolite concentrations revealed that the rate of ATP turnover (calculated from the amounts of end products accumulated and phosphagen utilized) rose only slightly between 0 and $12^{\circ} \mathrm{C}$ (from 5.2 to $7.3 \mu \mathrm{mol} \cdot \mathrm{g}^{-1} \mathrm{~d} . \mathrm{w} \cdot \mathrm{h}^{-1}$ ), while it increased more steeply at higher temperatures $\left(11 \mu \mathrm{mol} \cdot \mathrm{g}^{-1} \mathrm{~d} . \mathrm{w} \cdot \mathrm{h}^{-1}\right.$ at $16^{\circ} \mathrm{C}$ and $18.6 \mu \mathrm{mol} \cdot \mathrm{g}^{-1} \mathrm{~d}$. w. $\cdot \mathrm{h}^{-1}$ at $20^{\circ} \mathrm{C}$ ).

The experiments also indicate that the physiological state of the lugworm depends to some extent on the season. In winter, the tolerance of anoxia at temperatures above $7^{\circ} \mathrm{C}$ was found to be clearly reduced, whereas specimens obtained in autumn did not significantly differ from those studied in May (described above; Schmidt et al., 1992).

\section{METABOLISM RELATED TO REPRODUCTION AND DEVELOPMENT}

Two review articles have been published fairly recently which cover the reproduction and development of Arenicola marina in particular (Howie, 1984) and of polychaetes in general (Bentley \& Pacey, 1992). Therefore, we will deal here only with new results concerned with certain metabolic aspects of the topic.

The lugworm, like most polychaetes, is dioecious; eggs and sperm develop in the coelomic fluid to be shed into the ambient water via the nephridia. In the East Frisian Wadden Sea, gamete development starts in May or June resulting in an increase of the metabolic rate as indicated by rising oxygen consumption (Schöttler, 1989). This coincides with a striking reduction in the tolerance of hypoxia towards the spawning period in September and October.

Obviously, the developing gametes (like all other cells of Arenicola) are adapted to regular periods of hypoxia. However, no details of their anaerobic metabolism are known, except that sperm contains phosphorylase and comparatively high activities of alanopine dehydrogenase (Plate, 1991), which may suggest that alanopine is formed as the end product of glycogen degradation.

Some special features of metabolism become evident in the course of gamete development during summer. This is particularly the case in sperm cells, which aquire a phosphagen system of their own: phosphocreatine and creatine kinase instead of phosphotaurocyamine and taurocyamine kinase present in tissue cells (Kamp \& Juretschke, 1989b; Thiel \& Kamp, 1990; Plate 1991). Mature sperm cells are equipped with high creatine kinase activity.

When "epidemic" spawning occurs in autumn, lugworms do not leave their burrows. At low tide, sperm pools can then be observed on the sediment surface, while the oocytes 
are retained in the burrows (Bentley \& Pacey, 1992). For fertilization, sperm cells have to find their way into the burrows of the females. They must be able, therefore, to swim persistently for long periods, although assisted by the pumping activity of the adults.

Active sperm cells use phospocreatine presumably as a shuttle, transferring energyrich phosphate from the mitochondrion to the axonema. There, ATP is resynthesized and subsequently utilized by dynein ATPase providing the energy necessary for the sliding of the microtubuli. (A similar shuttle is present in mammalian heart muscle where phosphocreatine is produced by transphosphorylation from ATP catalysed by a mitochondrial creatine kinase and then carried to the contractile apparatus for resynthesis of ATP by a different type of creatine kinase.) In lugworm sperm likewise, two distinct creatine kinases have been detected which differ in molecular mass and isoelectric point (Thiel \& Kamp, 1990; Englisch \& Kamp, 1992). Moreover, one of these, CK1, is bound to mitochondrial structures, whereas the other, CK2, is present in cytosol. In the mature sperm cell the activity of CK2 by far exceeds that of CK1. These findings obviously indicate a shuttle function of phosphocreatine, while its use as energy reserve seems out of the question as it would be absolutely insufficient. (Since no isoenzymes of taurocyamine kinase have been detected, the shuttle function appears to be specific of the phosphocreatine/creatine kinase system.)

A high activity of hydroxyacyl-CoA dehydrogenase assayed in lugworm sperm (Plate, 1991) suggests that in aerobic metabolism particularly fat is used as a source of energy.

Whereas larval and early post-larval development in winter take place probably in the lower tidal zone, the juvenile lugworms settle close to the high-water line in spring where they start digging burrows and living like the adults (Farke \& Berghuis, 1979a, b; Reise, 1985). There, they are comparatively safe from (aquatic) predators and, in addition, do not encounter competition by adults. On the other hand, the environmental conditions are especially harsh, due to extended emersion periods (10 hours of even longer). As investigations have shown, juveniles employ the same mode of anaerobic metabolism as adults (Schiedek \& Schöttler, 1988, 1990a), although their tolerance of hypoxia is clearly lower (presumably because of their small reserves). On the other hand, their capability to maintain an aerobic metabolism exceeds that of adults (which may be due to more favourable conditions of oxygen supply including short distances of diffusion and transport); in vitro no symptoms of anaerobiosis have been detected at a $\mathrm{pO}_{2}$ of 15 Torr (whereas metabolism of adults is fully anaerobic at that $\mathrm{pO}_{2}$ ). In the natural habitat they did accumulate $2-6 \mu \mathrm{mol} \cdot \mathrm{g}^{-1} \mathrm{~d}$. w. succinate during 5 to 6 hours of emersion (as compared to $8-15 \mu \mathrm{mol} \cdot \mathrm{g}^{-1} \mathrm{~d}$. w. during an equal period of anoxia). This shows a partially anaerobic metabolism.

Close to the high-water line, salinity fluctuations during low tide are particularly large and juvenile lugworms living there in the upper layer of sediment are likely to encounter osmotic stress. According to ecological studies carried out in the tidal flats of Sylt Island, a correlation exists between the extent of salinity change and population density. The latter was very low in the vicinity of fresh-water run-offs from the neighbouring dunes, where salinity changes were at a maximum $(>15 \%$ in the interstitial water), but comparatively high in more protected areas close by (Schiedek \& Schöttler, 1988, 1991).

The juvenile lugworms responded to changes of salinity by reversible swelling due to 
passive water influx into tissues and coelomic fluid. The concentrations of glycine and alanine in the cells, however, did not change during these short-term fluctuations.

\section{CONCLUSIONS}

Several of the physiological properties of Arenicola described above must be seen as the result of an adaptation to the special conditions of its environment. Comparative investigations have shown that these or similar features are characteristic of many benthic annelids and, in addition, of several members of other systematic groups such as sipunculids, echiurids, priapulids, some gastropods and, particularly, many bivalves, i.e. the majority of larger animals living in similar habitats. Therefore, the lugworm has been established as a truly representative or "model" animal. The profound knowledge of its physiology provides a solid basis for understanding the interaction between this animal and its environment. Therefore, Arenicola is a particularly suitable object for investigating the conditions of its environment, including problems resulting from human activities.

\section{LITERATURE CITED}

Abbott, W. \& Awapara, J., 1961. Sulfur metabolism in the lugworm Arenicola cristata. - Biol. Bull. mar. biol. Lab., Woods Hole 119, 357-370.

Barrow, M. J. \& Wells, R. G. M., 1982. Ventilation and oxygen extraction in an Arenicolid polychaete. - Comp. Biochem. Physiol. 73 A, 491-495.

Batrel, Y. \& de Gal, Y., 1984. Nitrogen metabolism in Arenicola marina: characterization of an NADdependent glutamate dehydrogenase. - Comp. Biochem. Physiol. 78 B, 119-124.

Baumfalk, Y. H., 1979a. The pumping activity of Arenicola marina. - Neth. J. Sea Res. 13, 422-427.

Baumfalk, Y. H., 1979b. Heterogenous grain size distribution in tidal flat sediment caused by bioturbation activity of Arenicola marina. - Neth. J. Sea Res. 13, 428-440.

Bentley, M. G. \& Pacey, A. A., 1992. Physiological and environmental control of reproduction in polychaetes. - Oceanogr. mar. Biol. 30, 443-481.

Clark, M. E., 1968a. Free amino-acid levels in the coelomic fluid and body wall of polychaetes. - Biol. Bull. mar. biol. Lab., Woods Hole 134, 35-47

Clark, M. E., 1968b. A survey of the effect of osmotic dilution on free amino acids of various polychaetes. - Biol. Bull. mar. biol. Lab., Woods Hole 134, 252-260.

Conti, E. \& Toulmond, A., 1986. Ventilatory response to ambient hypo- and hypercapnia in the lugworm Arenicola marina. - J. comp. Physiol. (B) 156, 797-802.

Dejours, P. \& Toulmond, A., 1988. Ventilatory reactions of the lugworm Arenicola marina to ambient water oxygenation changes: a possible mechanism. - Physiol. Zool. 61, 407-414.

Duchateau-Boisson, G., Jeuniaux, C. \& Florkin, M., 1961. Rôle de la variation de la composante amino-acide intracellulaire dans l'euryhalinité d'Arenicola marina. - Archs. int. Physiol. Biochem. 69, 30-35.

Eberhardt, J., 1988. Untersuchungen zur Verdauungsphysiologie des Wattwurms Arenicola marina (Polychaeta, Annelida) unter besonderer Berücksichtigung der proteolytischen Enzyme. Diss., Univ. Münster, $192 \mathrm{pp}$.

Eberhardt, J., 1992. Isolation and characterization of five serine proteases with trypsin-, chymotrypsin- and elastase-like characteristics from the gut of the lugworm Arenicola marina. - J. comp. Physiol. (B) 162, 159-167.

Englisch, H., 1989. Die Regulation des Energiestoffwechsels bei fakultativ anaeroben Evertebraten: Untersuchungen an Arenicola marina unter spezieller Berücksichtigung von Eigenschaften und Bedeutung der Pyruvatkinase. Diss., Univ. Münster, 248 pp. 
Englisch, H. \& Kamp, G. 1992. The creatine kinase from spermatozoa of Arenicola marina. - Verh. dt. Zool. Ges. 85, 138.

Everaarts, J. M. \& Weber, R. E., 1974. Effects of inorganic anions and cations on $\mathrm{O}_{2}$ binding of haemoglobin from Arenicola marina. - Comp. Biochem. Physiol. 48 A, 507-520.

Farke, H. \& Berghuis, E. M., 1979a. Spawning, larval development and migration behaviour of Arenicola marina in the laboratory. - Neth. J. Sea Res. 13, 512-528.

Farke, H. \& Berghuis, E. M., 1979b. Spawning, larval development and migration behaviour of Arenicola marina under field conditions in the Western Wadden Sea. - Neth. J. Sea Res. 13, 529-535.

Felbeck, H., 1980. Investigations of the role of amino acids in anaerobic metabolism of the lugworm Arenicola marina. - J. Comp. Physiol. (B) 137, 183-192.

Felbeck, H. \& Grieshaber, M. K., 1980. Investigations on some enzymes involved in the anaerobic metabolism of amino acids of Arenicola marina. - Comp. Biochem. Physiol. 66 B, 205-213.

Florkin, M. \& Schoffeniels, E., 1965. Euryhalinity and the concept of physiological radiation. In: Studies in comparative biochemistry. Ed. by K. A. Munday. Pergamon Press, Oxford, 6-40.

Freeman, R. F. H. \& Shuttleworth, T. J., 1977a. Distribution of dry matter between the tissues and coelom in Arenicola marina. - J. mar. biol. Ass. U. K. 57, 97-107.

Freeman, R. F. H. \& Shuttleworth, T. J., $1977 \mathrm{~b}$. Distribution of water in Arenicola marina equilibrated to diluted seawater. - J. mar. biol. Ass. U. K. 57, 501-519.

Garlick, R. L. \& Terwilliger, R. C., 1977. Structure and oxygen equilibrium of hemoglobin and myoglobin from the Pacific lugworm Abarenicola pacifica. - Comp. Biochem. Physiol. $57 \mathrm{~B}$, $177-184$.

Giere, O., 1992. Benthic life in sulfidic zones of the sea: Ecological and structural adaptations to a toxic environment. - Verh. dt. zool. Ges. 85, 77-93.

Gibbs, K. L. \& Bishop, S. H., 1977. Adenosine triphosphate-activated adenylate deaminase from marine invertebrate animals. - Biochem. J. 163, 511-516.

Groenendaal, H., 1979. On sulphide and the distribution of Arenicola marina in a tidal mud flat in the Dutch Wadden Sea. - Neth. J. Sea Res. 13, 562-570.

Groenendaal, H., 1980. Tolerance of the lugworm to sulphide. - Neth. J. Sea Res. 14, 200-207.

Groenendaal, H., 1981. The adaptation of Arenicola marina to sulphide solutions. - Neth. J. Sea Res. $15,65-77$.

Hobson, K. D., 1967. The feeding and ecology of two North Pacific Abarenicola species (Arenicolidae, Polychaeta). - Biol. Bull. mar. biol. Lab., Woods Hole, 133, 343-354.

Holst, H. \& Zebe, E., 1984. Absorption of volatile fatty acids from ambient water by the lugworm Arenicola marina. - Mar. Biol. 80, 125-130.

Holst, H. \& Zebe, E., 1986. Volatile fatty acid excretion during anaerobiosis in the lugworm Arenicola marina. - Comp. Biochem. Physiol. 83 A, 189-196.

Howie, D. I. D., 1984. The reproductive biology of the lugworm Arenicola marina. - Fortschr. Zool. $29,247-263$.

Hunfeld, A. \& Kamp, G., 1990. Regulation der Glykogen-Synthese nach biotopbedingter Anaerobiose: Untersuchungen am Wattwurm Arenicola marina. - Verh. dt. zool. Ges. 83, 535-536.

Hylleberg-Kristensen, J., 1972. Carbohydrases of some marine invertebrates with notes on their food and natural occurrence of the carbohydrates studied. - Mar. Biol. 14, 130-142.

Hylleberg-Kristensen, J., 1975. Selective feeding by Abarenicola pacifica with notes on A. vagabonda and a concept of gardening in lugworms. - Ophelia 14, 113-134.

Jacobsen, V. H., 1967. The feeding of the lugworm Arenicola marina. Quantitative studies. - Ophelia 9, 91-109.

Juretschke, H. P. \& Kamp, G., 1990a. In vivo ${ }^{13} \mathrm{C}-\mathrm{NMR}$ studies on the metabolism of the lugworm Arenicola marina. - Eur. J. Biochem. 193, 273-281.

Juretschke, H. P. \& Kamp, G., 1990b. Influence of intracellular pH on the reduction of energy metabolism during hypoxia in the lugworm Arenicola marina. - J. exp. Zool. 256, 255-263.

Kamp, G., 1986. Features of glycogen phosphorylase from the bodywall musculature of the lugworm Arenicola marina and the mode of activation during anoxia. - Biol. Chem. Hoppe-Seyler 367, 109-117.

Kamp, G., 1992. Intracellular reactions controlling environmental anaerobiosis in the marine annelid 
Arenicola marina: a fresh look at old pathways. In: Surviving hypoxia. Mechanisms of control and adaptation. Ed. by P. W. Hochachka, P. L. Lutz, T. Sick, M. Rosenthal \& G. van den Thillart. CRC-Press, Boca Raton, 3-17.

Kamp, G. \& Juretschke, H. P., 1989a. Hypercapnic and hypocapnic hypoxia in the lugworm Arenicola marina. A. ${ }^{31}$ P-NMR study, - J. exp. Zool. 252, 219-227.

Kamp, G. \& Juretschke, H. P., 1989b. Phosphagen heterogeneity during the reproductive cycle in the lugworm Arenicola marina. - Naturwissenschaften 76, 275-276.

Kamp, G. \& Winnemöller, M, 1992. Partially phosphorylated glycogen phosphorylase in the lugworm Arenicola marina: its regulatory function during hypoxia. - Biol. Chem. Hoppe-Seyler 373, 1193-1200.

Kermack, D. M., 1955. The anatomy and physiology of the gut of the polychaete Arenicola marina. Proc, Zool. Soc. London 125, 347-381.

Kreutzer, U., Siegmund, B. \& Grieshaber, M. K., 1989. Parameters controlling opine formation during muscular activity and environmental hypoxia. - J. comp. Physiol. (B) 159, 617-628.

Krogh-Rasmussen, K. \& Weber, R. E., 1979. Respiratory properties of erythrocruorin (extracellular hemoglobin) in the blood of the annelid Arenicola marina with special reference to the influence of salinity and temperature. - Ophelia 18, 151-170.

Krüger, F., 1958a. Zur Ernährungsphysiologie von Arenicola marina. - Zool. Anz. 22 (Suppl.), $115-120$.

Krüger, F., 1958b. Zur Atmungsphysiologie von Arenicola marina. - Helgoländer wiss. Meeresunters. $6,193-201$

Krüger, F., 1959. Zur Wirkungsweise des Hämoglobins von Arenicola marina. - Zool. Anz. 23 (Suppl.), 348-351.

Krüger, F., 1964. Messungen der Pumpaktivität von Arenicola marina im Watt. - Helgoländer wiss. Meeresunters. 11, 70-91.

Krüger, F., 1971. Bau und Leben des Wattwurms Arenicola marina. - Helgoländer wiss. Meeresunters. $22,1-54$.

Liefken, W., Boon, J. J. \& Leeuw, J. W. de, 1979. On the occurrence of alkyl-and alk-1-enyl-diacyl glycerides in the lugworm Arenicola marina. - Neth. J. Sea Res. 13, 479-486.

Longbottom, M. R., 1970. The distribution of Arenicola marina with particular reference to the effects of particle size and organic matter in sediments. - J. exp. mar. Biol. Ecol. 5, 138-157.

Longbottom, M. R., 1970. Distribution of the digestive enzymes in the gut of Arenicola marina. - J. mar. biol. Ass. U. K. 50, 121-128.

Mangum, C. P., 1973. Evaluation of the functional properties of invertebrate hemoglobins. - Neth. J. Sea Res. 7, 303-315.

Mangum, C. P., 1976. The oxygenation of hemoglobin in lugworms. - Physiol. Zool. 49, 85-99.

May, R. D., 1972. The effects of oxygen concentration and anoxia on respiration of Abarenicola pacifica and Lumbinereis zonata (Polychaeta). - Biol. Bull. mar. biol. Lab., Woods Hole 142, 71-83.

Oglesby, L. C., 1973. Salt and water balance in lugworms (Polychaeta, Arenicolidae) with particular reference to Abarenicola pacifica in Coos Bay, Oregon. - Biol. Bull. mar. biol. Lab., Woods Hole, $145,180-199$

Patel, S. \& Spencer, C. P., 1963. The oxidation of sulphide by the haem compounds from the blood of Arenicola marina. - J. mar. biol. Ass. UK 43, 165-175.

Pionetti, J. M. \& Toulmond, A., 1980. Tide related changes of volatile fatty acids in the blood of the lugworm Arenicola marina. - Can. J. Zool. 58, 1723-1727.

Plate, N., 1991. Untersuchungen über das Phosphagensystem in den Spermazellen des Wattwurms Arenicola marina. Dipl. Arb., Univ. Münster, $71 \mathrm{pp}$.

Pörtner, H. O., Surholt, B. \& Grieshaber, M. K., 1979. Recovery from anaerobiosis of the lugworm Arenicola marina: changes of metabolite concentrations in the body-wall musculature. - J. comp. Physiol. 133, 227-231.

Reise, K., 1985. Tidal flat ecology. Springer, Berlin, $191 \mathrm{pp}$.

Reitze, M. \& Schöttler, U., 1989. The time dependence of adaptation to reduced salinity in the lugworm Arenicola marina (Annelida, Polychaeta). - Comp. Biochem. Physiol. 93 A, 549-559.

Reitze, M., Schöttler, U. \& Luftmann, H., 1989. Alanine metabolism of the lugworm Arenicola marina (Annelida, Polychaeta) during adaptation to reduced salinity. - Comp. Biochem. Physiol. $93 \mathrm{~B}$, 689-696. 
Rijken, M., 1979. Food and food uptake in Arenicola marina. - Neth. J. Sea Res. 13, 406-421.

Robertson, J. D., 1949. Ionic regulation in some marine invertebrates. - J. exp. Biol. 26, 182-200.

Schiedek, D. \& Schöttler, U., 1988. The influence of oxygen and salinity on the growth and abundance of juvenile Arenicola marina. - Verh. dt. zool. Ges. 81, 329.

Schiedek, D. \& Schöttler, U., 1990a. The energy production of juvenile Arenicola marina (Polychaeta) under anoxic and hypoxic conditions. - Helgoländer Meeresunters. 44, 135-145.

Schiedek, D. \& Schöttler, U., 1990b. The importance of free amino acids to hyper-osmotic adaptation: investigations on polychaetes. - Verh. dt. zool. Ges. 83, 329.

Schiedek, D. \& Schöttler, U., 1991. The influence of freshwater runoff on the population density of juvenile Arenicola marina (Polychaeta). In: Estuaries and coasts: spatial and temporal intercomparisons, Ed. by M. Elliott \& J. P. Ducrotoy. Olsen \& Olsen, Fredenborg, 195-200.

Schmidt, R., Schiedek, D. \& Schöttler, U., 1992. The influence of temperature on the anaerobic metabolism of Arenicola marina (Polychaeta). - Verh. dt. zool. Ges. 85, 167.

Schöttler, U., 1980. Der Energiestoffwechsel bei biotopbedingter Anaerobiose. - Verh. dt. zool. Ges. $73,228-240$.

Schöttler, U., 1983. Untersuchungen zur Bildung von Propionat aus Succinat in submitochondrialen Fraktionen aus dem Hautmuskelschlauch von Arenicola marina. - Verh. dt. zool. Ges. 76, 321.

Schöttler, U., 1986. Weitere Untersuchungen zum anaeroben Energiestoffwechsel des Polychaeten Arenicola marina. - Zool. Beitr. 30, 141-152.

Schöttler, U., 1989. Anaerobic metabolism in the lugworm Arenicola marina during low tide: the influence of developing reproductive cells. - Comp. Biochem. Physiol. 92 A, 1-7.

Schöttler, U. \& Bennet, E. M., 1991. Annelids. In: Metazoan life without oxygen. Ed. by C. Bryant. Chapman \& Hall, London, 165-185.

Schöttler, U., Daniels, D. \& Zapf, K., 1990. Influence of anoxia on adaptation of euryhaline polychaetes to hypoosmotic conditions. - Mar. Biol. 104, 443-451.

Schöttler, U., Surholt, B. \& Zebe, E., 1984a. Anaerobic metabolism in Anaerobic marina and Nereis diversicolor during low tide. - Mar. Biol. 81, 69-73.

Schöttler, U., Wienhausen, G. \& Westermann, J., 1984b. Anaerobic metabolism in the lugworm Anaerobic marina: The transition from aerobic to anaerobic metabolism. - Comp. Biochem. Physiol. 79 B, 93-103.

Schöttler, U. \& Wienhausen, G., 1981. The importance of the phosphoenolpyruvate carboxykinase in the anaerobic metabolism of two marine polychaetes. - Comp. Biochem. Physiol. 68 B, 41-48.

Schöttler, U., Wienhausen, G. \& Zebe, E., 1983. The mode of energy production in the lugworm Anaerobic marina at different oxygen concentrations. - J. comp. Physiol. (B) 149, 547-555.

Schroff, G. \& Schöttler, U., 1977. Anaerobic reduction of fumarate in the body-wall musculature of Anaerobic marina (Polychaeta). - J. comp. Physiol. 116, 325-336.

Schroff, G. \& Zebe, E., 1980. The anaerobic formation of propionic acid in the mitochondria of the lugworm Arenicola marina. - J. comp. Physiol. 138, 35-41.

Shumway, S. E., 1979. The effects of body-size, oxygen tension and mode of life on the oxygen uptake rates of polychaetes. - Comp. Biochem. Physiol. 64 A, 273-278.

Shumway, S. E. \& Davenport, J., 1977. Some aspects of the physiology of Anaerobic marina (Polychaeta) exposed to fluctuating salinities. - J. mar. biol. Ass. U. K. 57, 907-924.

Siegmund, B., Grieshaber, M. K., Reitze, M. \& Zebe, E., 1985. Alanopine and strombine are end products of anaerobic glycolysis in the lugworm Anaerobic marina (Annelida, Polychaeta). Comp. Biochem. Physiol. 82 B, 337-345.

Sticher, U., 1985. Untersuchungen zum Stoffwechsel von D-Alanin in marinen Anneliden. Dipl. Arb., Univ. Münster, 87 pp..

Surholt, B., 1977a. Production of volatile fatty acids in the anaerobic carbohydrate catabolism of Arenicola marina. - Comp. Biochem. Physiol. 58 B, 147-150.

Surholt, B., $1977 \mathrm{~b}$, The influence of oxygen deficiency and electrical stimulation on the concentrations of ATP, ADP, AMP and phosphotaurocyamine in the body-wall musculature of Arenicola marina. - Hoppe-Seyler's Z. physiol. Chem. 358, 1455-1461.

Surholt, B., 1979. Taurocyamine kinase from body-wall musculature of the lugworm Arenicola marina. - Eur. J. Biochem. 93, 279-285.

Thiel, U. \& Kamp, G., 1990. Localization of creatine kinase in spermatozoa of the lugworm Arenicola marina. - Verh. dt. zool. Ges. 83, 592-593. 
Toulmond, A., 1971a. Détermination du volume des compartiments coelomique et circulatoire chez l'Arénicole, Polychète. - C. r. hebd. Séanc. Acad. Sci., Paris 272, 257-260.

Toulmond, A., 1971b. Sur une particularité du pouvoir tampon de l'hémoglobine d'Arénicole (Arenicola marina, Annélide. Polychète). - C. r. hebd. Séanc. Acad. Sci., Paris 272, 3184-3187.

Toulmond, A., 1973. Tide related changes of blood respiratory variables in the lugworm. - Respir. Physiol. 19, 130-144.

Toulmond, A., 1975. Blood $\mathrm{O}_{2}$ transport and metabolism of the confined lugworm. - J. exp. Biol, 63, $647-660$.

Toulmond, A. \& Tschernigovtzeff, C., 1984. Ventilation and respiratory gas exchanges of the lugworm Arenicola marina as functions of ambient $\mathrm{pO}_{2}$ (20-700 Torr). - Respir. Physiol. 57, 349-363.

Toulmond, A., Tschernigovtzeff, C., Greber, G. \& Jouin, C., 1984. Epidermal sensitivity to hypoxia in the lugworm. - Experientia 40,541-543.

Vismann, B., 1991. Sulfide tolerance: physiological mechanisms and ecological implications. Ophelia 34, 1-27.

Völkel, S. \& Grieshaber, M. K., 1992. Mechanisms of sulphide tolerance in the peanut worm Sipunculus nudus (Sipunculidae) and the lugworm, Arenicola marina. - J. comp. Physiol. (B) 162, 469-477.

Völkel, S. \& Grieshaber, M. K., 1994. Oxygen-dependent sulfide detoxification in the lugworm Arenicola marina. - Mar. Biol. 118, 137-147.

Waxman, L., 1971. The hemoglobin of Arenicola cristata. - J. biol. Chem. 246, 7318-7327.

Weber, R. E., 1970. Relations between functional and molecular properties of annelid haemoglobins. Interaction between haems in the haemoglobin of Arenicola marina. - Comp. Biochem. Physiol. 35, 179-189.

Weber, R. E., 1972. On the variation in oxygen-binding properties in haemoglobins of lugworms (Arenicolidae, Polychaeta). In: Fifth European Marine Biology Symposium. Ed. by B. Battaglia. Piccin, Padova, 231-243.

Weber, R. E., 1978. Respiratory pigments. In: Physiology of annelids. Ed. by P. J. Mill. Acad. Press, London, 393-446.

Weber, R. E. \& Pauptit, E., 1972. Molecular and functional heterogeneity of myoglobin from the polychaete Arenicola marina. - Archs. Biochem. Biophys. 148, 322-324.

Wells, G. P., 1949. Respiratory movements of Arenicola marina: intermittent irrigation of the tube and intermittent aerial respiration. - J. mar. biol. Ass. U. K. 28, 447-464.

Wells, R. G. M., 1973. Carbonic anhydrase activity in Arenicola marina. - Comp. Biochem. Physiol. 46 A, 325-331.

Wells, R. G. M., 1974. Hydrogen ion activity in polychaete body fluids. - Comp. Biochem. Physiol. 49 A, 567-574.

Wells, R. G. M. \& Pankhurst, N. W., 1980. An investigation into the formation of sulphide and oxidation compounds from the hemoglobin of the lugworm Abarenicola affinis. - Comp. Biochem. Physiol. 66 C, 255-259.

Wienhausen, G., 1981. Anaerobic formation of acetate in the lugworm Arenicola marina. - Naturwissenschaften $68,206$.

Zebe, E., 1975. In-vivo-Untersuchungen über den Glukose-Abbau bei Arenicola marina (Annelida, Polychaeta). - J. comp. Physiol. 101, 133-145. 